\title{
Developing Culturally Effective Strategies for Chinese to English Geotourism Translation by Corpus-Based Interdisciplinary Translation Analysis
}

\author{
Qiang (Jason) $\mathrm{Li}^{1} \cdot$ Ruixue (Rachel) $\mathrm{Wu}^{2} \cdot$ Young $\mathrm{Ng}^{3}$
}

Received: 10 March 2021 / Accepted: 29 September 2021 / Published online: 16 December 2021

(c) The Author(s) 2021

\begin{abstract}
As a new field of translation with its own special genre, geotourism has not yet been firmly established because geotourism translations are currently not of a sufficient professional standard. This situation does not provide geotourists with the genre's full target of enjoyment, learning and engagement through science popularisation tourism activities. In order to better meet these three definitive purposes in geotourism, this study analyses the three basic categories of geotourism—geological features (GFs), geological processes (GPs) and cultural elements (CEs) - to determine effective strategies of geotourism translation from Chinese into English. Challenges in translation include scientific jargon, language style and cultural gaps. In this article, the advantages of Hu's Eco-translatology theory are explained and used for minimising translation problems; and the corpus linguistics method, superior for quantitative and qualitative analysis, is utilised. As well, digital auxiliary tools Tmxmall (2014) and Sketch Engine (2003) were employed to facilitate corpus research. Through analysis, effective strategies in each of the key geotourism categories, GFs, GPs and CEs, were identified, shaped and recommended for future translators' attention. In the results, literal translation, transliteration and free translation, addition and use of official UNESCO names were recommended to render GFs. Division and shift translation, literal translation and shift and division were recommended for GPs. Literal translation, transliteration and free translation and addition were recommended for CEs. Since this is an initial investigation in the genre of geotourism, this study has attempted to build a model platform for future study and wider research in geotourism translation and translation pedagogy for the improvement of geotourism translation quality.
\end{abstract}

Keywords Geotourism translation · Translation strategies $\cdot$ Eco-translatology $\cdot$ Corpus linguistics

\section{Background}

General concern for land and ocean degradation has been growing since the late twentieth century. This has led to a strengthening of the conservation movement which involves the need for public awareness of the dilemma and better understanding of planet Earth. This impetus led to the birth of geotourism which seeks to pursue conservation and

Qiang (Jason) Li

qiang.li@lancaster.ac.uk

1 Department of Linguistics and English Language, Lancaster University, Lancaster, UK

2 Leiden University Centre for Linguistics (LUCL), Leiden University, Leiden, Netherlands

3 Geological Society of Australia, 8/141 Peats Ferry Rd, Hornsby, NSW 2077, Australia public education as its definitive purposes (Fig. 1). There are various definitions of geotourism (Hose 1996; National Geographic 2005; Joyce 2006; Dowling and Newsome 2006) whether they are geological or geographical in nature, and they are all taking geology and landscapes as a foundation to promote the geographical character of a place (National Geographic 2005). The Geological Society of Australia (GSA) most concisely defines it as a 'holistic nature-based tourism focusing on an area's geology and landscape as the basis for providing visitor engagement, learning and enjoyment' (GSA 2015).

In turn, the growth of geotourism has increased the amount of Chinese to English translation in nature tourism activities in China, especially after the establishment of UNESCO Global Geoparks in 2004 which encourages opening of geoparks to non-Chinese-speaking tourists. Science popularisation of geotourism and geoparks aims at transmitting information and meaning to the general public 


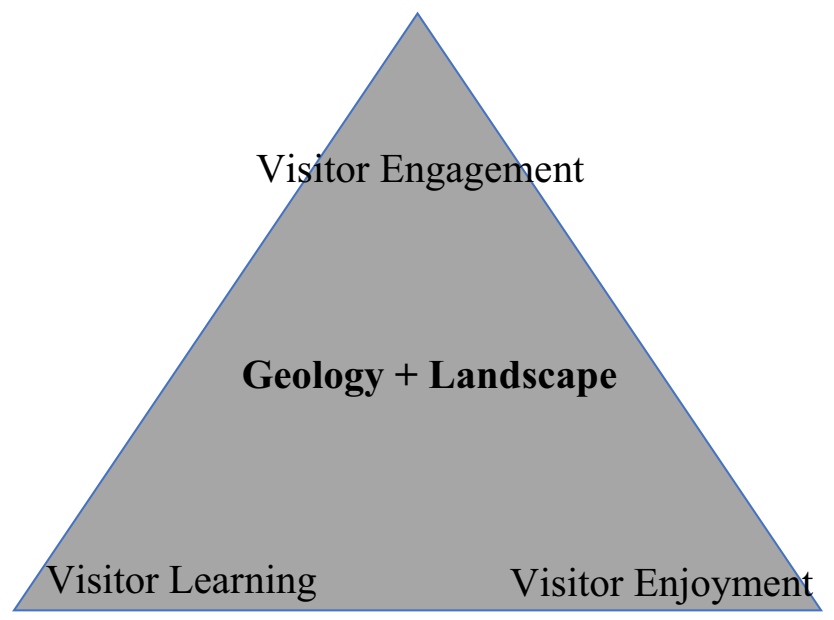

Fig. 1 Diagram explaining the purpose of geotourism (GSA 2015)

and therefore it calls for accuracy in translation. However, geopark development also presents serious concerns to the geopark management as geotourism translation in geoparks involves challenges in technical language, language style and cultural gaps to geotourism translators. Therefore, the need for effective geotourism translation has become increasingly important.

Geoparks, by their nature, are the main focus of geotourism. Geodata is found in a variety of locations in Chinese UNESCO Global Geoparks: on the signage and interpretation boards of geological museums, visitor centres and on walking trails of geoparks, national parks or reserves. This data can include translating geological phenomena (GFs and GPs) and CEs, all of which are key elements of geotourism. The concept of geological phenomena (GFs and GPs) was defined by Dowling (2013) as the overall description of all the natural features and processes of Earth formation. While GFs refer to any physical feature, but it is usually rock or landform of the Earth's surface that is formed by a single GP or a combination of different processes. A feature (GF) could be a volcano, a desert or a cave. A process (GP) could be a volcanic eruption (formation of a volcano), sedimentation (which can result in a desert) or water or wind erosion (which may result in the formation of a cave). Dowling (2013) helpfully explains that CEs in geoparks are both past (historical accounts) and present (community customs and culture), such as life style of people.

Geotourism translation from Chinese to English has, in sum, to address three main challenges: linguistics, communication and culture. Firstly, there are many geological scientific jargons and expressions in GFs. These scientific terms are difficult to interpret into their English equivalent counterparts. The nature of the two language structures is so different that another challenge presents itself in the GPs. This is because the process in the Chinese source text (ST) is expressed in a complex and convoluted style while English target text (TT) demands some simple and short sentences which are concise and clear. Moreover, the passive voice sometimes needs to be added and word order changed to render active voice in Chinese ST to translate into English GPs. The nature of a third challenge stems from translating unique Chinese CEs (poetry, religion, traditions, symbols and architecture). Native Chinese have difficulty in interpreting these to another culture because there is no common CE. Hence, in geotourism, it is sometimes difficult to achieve semantic equivalence, style equivalence and cultural equivalence between Chinese and English.

Some current examples from Chinese UNESCO Geoparks can clearly illustrate the above problems. For example, in Taishan UNESCO Global Geopark, ‘天贶殿' was translated into 'Tian Kuang Hall'. Here, '贶' in Chinese culture means 'the emperor's residence'. Therefore, '贶' should be translated into 'palace' instead of 'hall'. In English, a 'hall' is a public meeting place for formal events, whereas a 'palace' is a private home that would not only probably be grand but bound by many formal protocols. Similarly, “延禧殿' should be rendered into 'Yan Xi Palace' rather than 'Yan Xi Hall'. Apart from the wrong choice of translation, another problem is lack of consistent translation of the same Chinese term. For instance, '泰山' was variously translated into 'Mount Tai', 'Taishan Mountain', 'Mountain Taishan' and 'Mount Taishan'. These are a couple of the simpler examples of inadequate translation. The other more complex challenges of scientific terms, contrasting grammar structures, and lack of shared cultural knowledge, strengthen the argument for a systematic approach to geotourism translation from Chinese to English.

Therefore, the purpose of this paper is to outline the problems of translating GFs, GPs and CEs and identify effective approaches of addressing these problems for the successful and long-term development of geoparks in China. To fulfil the research purpose, first, a corpus is built and then utilised to find effective translation strategies through using the methodology of corpus linguistics in a research process. Thus, an attempt is made to meet the challenges of scientific jargon, language styles and cultural gaps when translating from Chinese to English of the three main categories (GFs, GPs and CEs) of geotourism. Moreover, data of geotourism translation in GFs, GPs and CEs in geoparks are analysed within a theoretical framework of Hu's Eco-translatology. This theoretical framework offers direction for difficulties and therefore some effective translation strategies can be recommended to bridge these technical, grammatical and cultural difficulties. Finally, the resulting effective strategies for improved geotourism translation in each category (GFs, GPs and CEs) will be summarised to build a model of translation approach based on the Hu's Eco-translatology theory. Thus recommendations will be made for the future 
application of translators when working from Chinese to English in geotourism data. This paper contains extensive linguistic terminology which is listed at the conclusion of the paper in the 'Appendix' section to assist readers with no translation background (Table 13).

\section{Literature Review}

Corpus linguistics for the purposes of translation strategies for tourism has been widely used in past research, and translation scholars have been involved in geotourism and geoparks. For the purposes of demonstrating corpus linguistics application as a methodology, a research example by Han and Wang (2014) will be described. They propose that English swear words, as a kind of culture-specific issue, in subtitling, are difficult to render into Chinese. They chose an Australian reality TV series called The Family to shape a parallel English to Chinese translation corpus. The authors found some subtitling translation strategies do not express the authentic sound of Chinese and also at the same time that it is hard to retain the original sense of the English swear words. Therefore, they adopt a 'reverse engineering' model of translation (looking at desired effect not content) to analyse them and consequently find the application of this model facilitates authenticity in the Chinese subtitles. They conclude that in order to retain the communicative intention of the original swearing, the translator can simply employ the 'category shift' and 'literal' subtitle two important features: one, that research can shape a customised corpus and that it does not merely have to use an existing corpus for research; and two, traditional translation methods do not always deliver effective results.

Furthermore, in regard to the complexity of translation methods and more relevantly to the topic of tourism, $\mathrm{Li}$ (2019) uses a corpus-based research method to study the translation for foreigners of a restaurant menu according to three categories: each dish's ingredients, cooking methods and culturally specific names. This author compares their translation in a parallel corpus, only to find these translations are not consistent or equivalent to Chinese because of oversimplification in translation strategies which prove inadequate. Li introduces the multimodal translation method, which includes Roman Jakobson's tripartite theory (1959), in order to improve the translation. Jakobson (1959) structured translation into three types: use of the same language, borrowing from another language or the use of symbols/ nonverbal signs. This author concludes that nonverbal signs, in this case, the application of Pinyin (Chinese Phonetic Alphabet), most easily facilitate translation for foreigners for understanding the ingredients, cooking methods and cultural background of dishes, especially when the Pinyin is supported with an attractive pictorial representation of the dish's cuisine artistry.

Tourism translation has facilitated translation techniques for rendering translation in geotourism. For example, Rezaei and Kuhi (2014) take two tourist guidebooks rendered by Beheshti and Hakimian from Persian into English as the corpus for the sake of developing translation strategies of cultural-specific items (CSIs). In the TT, they use Newmark's Model (1988) which analyses translation into two aspects: the effectiveness of the translation and the style of it in the TT. These authors, Rezaei and Kuhi (2014), collected data to analyse whether translators adopt the domestication or foreignisation in rendering CSIs. Their results illustrate that the optimised translation strategy in the two guidebooks is the Newmark's transference with the addition of some notes. The authors significantly conclude, although both foreignisation and domestication are applied in these two translated tourist guidebooks, foreignisation is the most common strategy used. Later, Zainal Arifin (2019) uses the Javanese tourism brochures of Wisata Kuliner di Kota Batil to further test Rezaei and Kuhi's (2014) research outcome. The author, Arifin (2019), states that in the process of Javanese to English translation, the gaps of understanding cultural words make it difficult for English and Javanese to be equivalent in meaning. This author claims that in order to tackle these non-equivalent cultural words, appropriate translation strategies should be adopted to generate the equivalent meaning. Therefore, this author explores the translation strategies of specific-culture terms (SCTs) in the translated Javanese tourism text by the descriptive qualitative method. To do this, the author employs an interactive model for data analysis: data simplification, data demonstration and its conclusion. He shows that when the translator needs to render these SCTs, the translation strategies used are mostly borrowing, borrowing with explanation, cultural substitution as well as adoption with explanation. This last research points to the complexity of translation methods even within a single technique such as foreignisation and that there is not a single dominant strategy (such as foreignisation) that can be effectively used but that in fact explanation can accompany foreignisation strategies. Thus, Arafin (2019) contrasts to the oversimplified findings of Rezaei and Kuhi (2014) who found foreignisation was the most common strategy.

This paper regards geotourism as a unique type of general tourism, related to nature tourism, and for that reason, earlier tourism research is relevant. However, rather than the broad spectrum of nature, geotourism is closely related to geoparks. A geopark is officially defined by The United Nations Educational, Scientific and Cultural Organisation (UNESCO 1999) as 'an area comprising one or more places with scientific significance and having archaeological, ecological and cultural values and geological value'. The researcher, $\mathrm{Ng}$ (2017), identifies geoparks as the cornerstone in geotourism. 
Gordon (2018) highlights the conservation, education and sustainable development via providing geological interpretation for tourists. The high level of interest in geoparks and the demand for more accurate geodata has propelled further research in geotourism and the global movement of people creates the need for effective translation strategies in geotourism. Corpus linguistics method is confirmed as an effective method, but although scholars have used corpus linguistics as a methodology, there is no apparent study in the particular area of geotourism translation using corpus linguistics, and also, there are no comparative translation strategies for geotourism. With the growth of the significance of geotourism, the need for informative and effective translation strategies is more urgently demanded. Therefore, this research will be a corpus-based translation study in Chinese to English geotourism translations.

\section{Research Questions and Objectives}

Based on the research gap of geotourism translation, two key research questions can be put forward as below:

a. How effective is the English translation in conveying the original geotourism messages in Chinese?

This would include various purposes of text such as description or explanation. For example, many geological terms and GPs need an explanation into English because of Chinese cultural background of colour, language or historical significance in the Chinese text (ST). If Chinese translators cannot make a clear and effective explanation to the target readers (TT), it will be difficult to understand these data.

The research objective to deal with this first question would include analysing corpus data to retrieve the nature of the patterns of translation in the comparative language.

b. In what specific ways can the current translation in geotourism be improved?

This question seeks to bring some translation discipline into the area of geotourism translation so that there would be consistency in the translation and interpretation of key terms and processes. This consistency would lessen confusion and dissatisfaction in the target readers. The translator needs to identify underlying assumptions behind the meaning of words, cultural knowledge that might be necessary to understand the term and gaps in the target language (TL) that need to be bridged in a concise manner.

Engaging in research of the second question (b) would entail comparison of efforts in different areas of geotourism (geological interpretation, geological description, for example) using corpora. It would also entail determining which criteria would best used to overcome ineffective translations. This in turn would invite analysis of translation strategies, and their application in corpora.

Through solving the above two key research questions, this paper aims to contribute to three different areas of research: a recommended standard approach for translation of geotourism, various types of education material and future support of geotourism translation. Firstly, the obtained research results will provide a standard of criteria to inform translators and benefit the output of geotourism translation, and secondly, provide materials for teaching and learning in modern education classes. For teaching, lecturers can impart translation strategies to help students select the effective translation strategies for geotourism translation. For example, in learning, based on corpus linguistics method, students can learn how to choose more appropriate translation strategies in order to minimise the negative language interference between ST and TT through parallel geotourism translation corpus. Consequently, this will lead to improving the quality of future geotourism translation. Most importantly, studies on geotourism translation may not only promote the interest and development of geotourism translation, but also provide reference tools for future geotourism translators and linguistic researchers of other languages.

\section{Corpus and Methodology}

\section{Data Collection Procedure}

A selection of Chinese to English translations used in Chinese geoparks, approved by UNESCO, was used as corpora for the case study. At present, geotourism is commonly practised in geoparks. Therefore, the focus is on geoparks for the following reasons: (1) geoparks are probably the best quality venues for geotourism; (2) tourism activities within geoparks are mostly associated to some degree with geology and geomorphology and therefore demand high linguistic detail for translating technical vocabulary. Moreover, these activities are usually also linked with ecological and CEs of the geoparks which may require complex linguistic treatment; (3) information and data are easier to collect from geoparks for this research. In this paper, the data were collected from the most commonly used information for tourists in the two renowned and typical global geoparks namely Yandangshan UNESCO Global Geopark and Danxiashan UNESCO Global Geopark. These two global geoparks were also chosen because (1) they are representative of translation problems currently facing most Chinese global geoparks and (2) they are two of the earliest global geoparks in the world and in China. They have both gone through stages of development and their interpretation system and translation materials have been regularly updated. The sources of data 
include brochures, pamphlets, interpretative panels, signs, display boards and museum displays which were readily free-of-charge to all tourists within the geoparks, especially at their entrances, visitor centres and museums. To avoid any bias, the data were only collected from easily available public sources as this was the area where many of translation problems were found. A series of procedures was illustrated below (Fig. 2).

The specific TSs and specific TPs for this research are shown in Fig. 3 and 4.

\section{Corpus Procedure}

After building the concordance (PGC), the corpus linguistics method was applied. First, the three categories (GFs, GPs and CEs) were retrieved from the concordance. The data retrieval steps are as follows: (1) click the Parallel Concordance at DASHBORD page; (2) click the ADVANCE at the PARALLEL CONCORDANCE page; (3) choose English in 'Search in' and then click CQL in Query type. Then follow the function formula as below:
Fig. 2 Diagram of analysis procedure

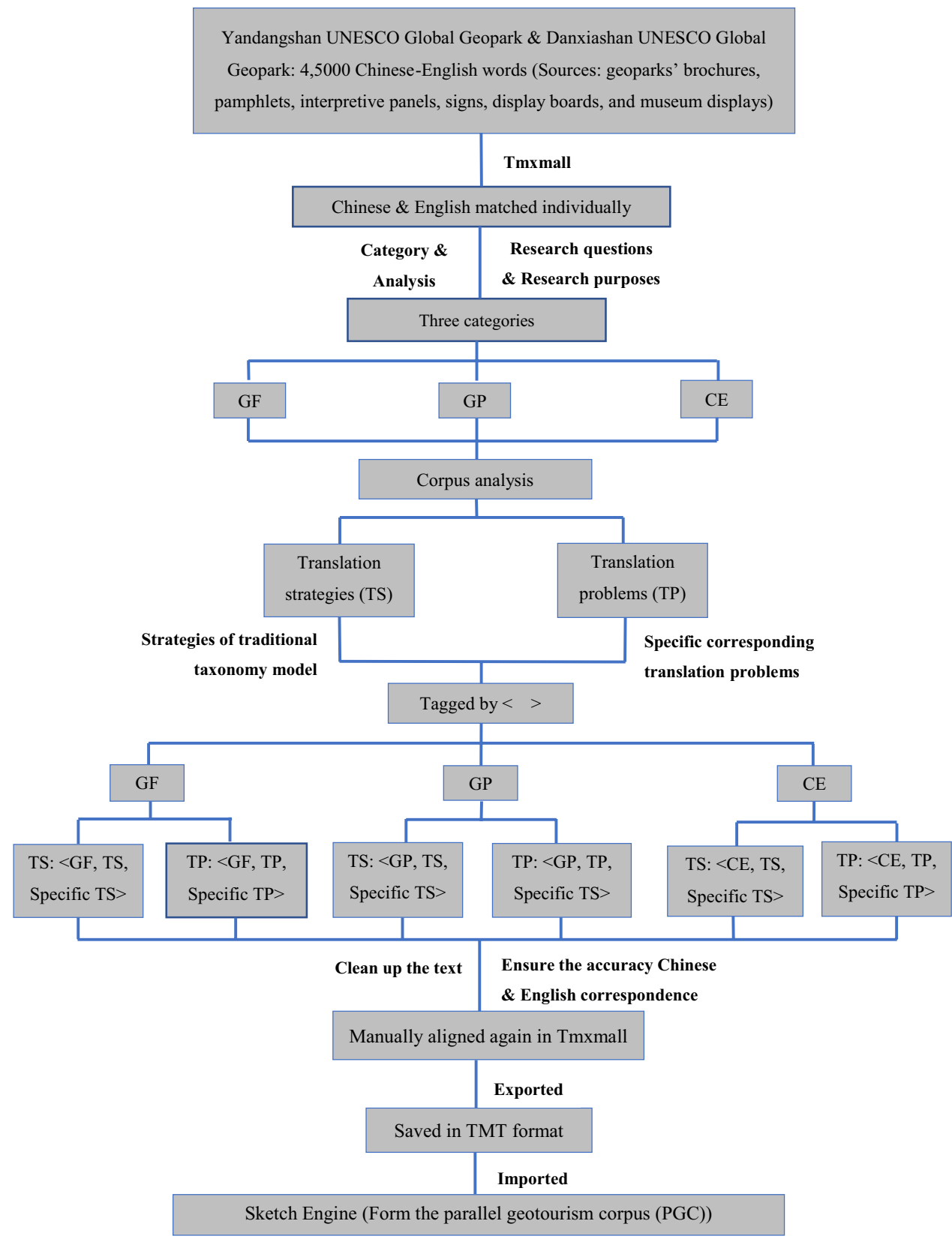


Fig. 3 Annotated specific TSs and comments

\begin{tabular}{cc}
\hline Specific Translation Strategy (TS) & Tag \\
\hline Free translation & Free Trans \\
Literal translation & Literal Trans \\
Foreignisation & Foreignisation \\
Addition & Addition \\
Shift & Shift \\
Division & Division \\
Division and Shift & DS Trans \\
Transliteration and Free translation & TF Trans \\
\hline
\end{tabular}

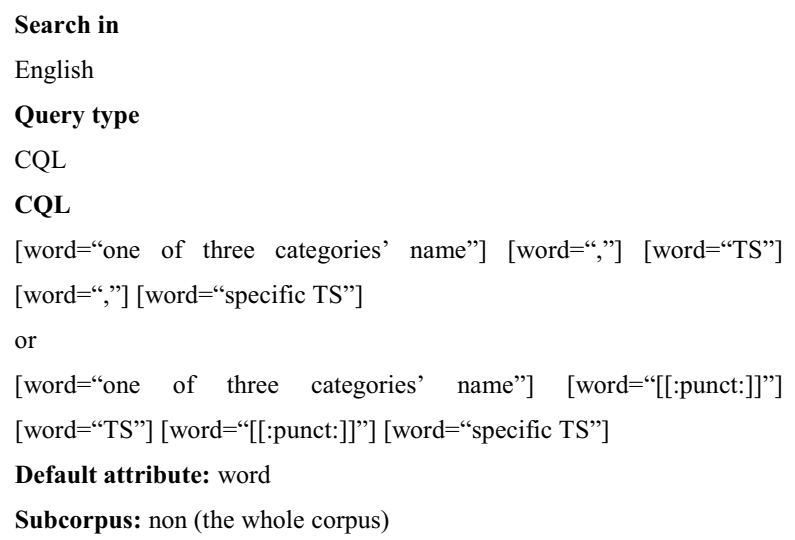

A bar chart was utilised to visually project the quantitative analysis of the translation strategies used in the three different categories. Finally, the reasons for using translation strategies for selected texts were summarised after analysis.

\section{Eco-translatology Application}

Geotourism is also a new direction within the discipline of geoscience. Many geoscientists are still trying to establish a solid theoretical foundation for geotourism to align it with other geosciences. This means terms and technical matters are yet to be standardised and therefore not are translation publications yet standardised in geotourism. Hence, in this research, Ecotranslatology, a translation theory, is used as a theoretical framework and platform to guide the quality of translation. This systematic translation theory was originally put forward by Chinese scholar, Hu (2001). He innovated an approach to translation based on the principles of Darwin's theory of natural selection and adaptation. It is an ecological approach to translation studies. His framework uses the translator as the dominant influence and aims at an ideal of cross-cultural balance. This procedure is described in the diagram (Fig. 5).

$\mathrm{Hu}$ states on the one hand that this theory refers to 'metaphorical reference' to adaption, and on the other hand, it refers to 'actual reference' in the text. Here, 'metaphorical reference' means translation ecology compared to natural ecology, while 'actual reference' means the translators compared to the translational eco-environment ( $\mathrm{Hu} 2003)$. Thus, he finally

Fig. 4 Annotated specific TPs

\begin{tabular}{cc}
\hline Specific Translation Problem (TP) & Tag \\
\hline Use Chinese Pinyin to Replace English Words & UCPREW \\
Mistranslated & Mistranslated \\
Not Translated & NT \\
Incongruent Translation for Same Name & ITSN \\
\hline
\end{tabular}


Fig. 5 'Adaptation/selection' of translation activity $(\mathrm{Hu}, 2003)$

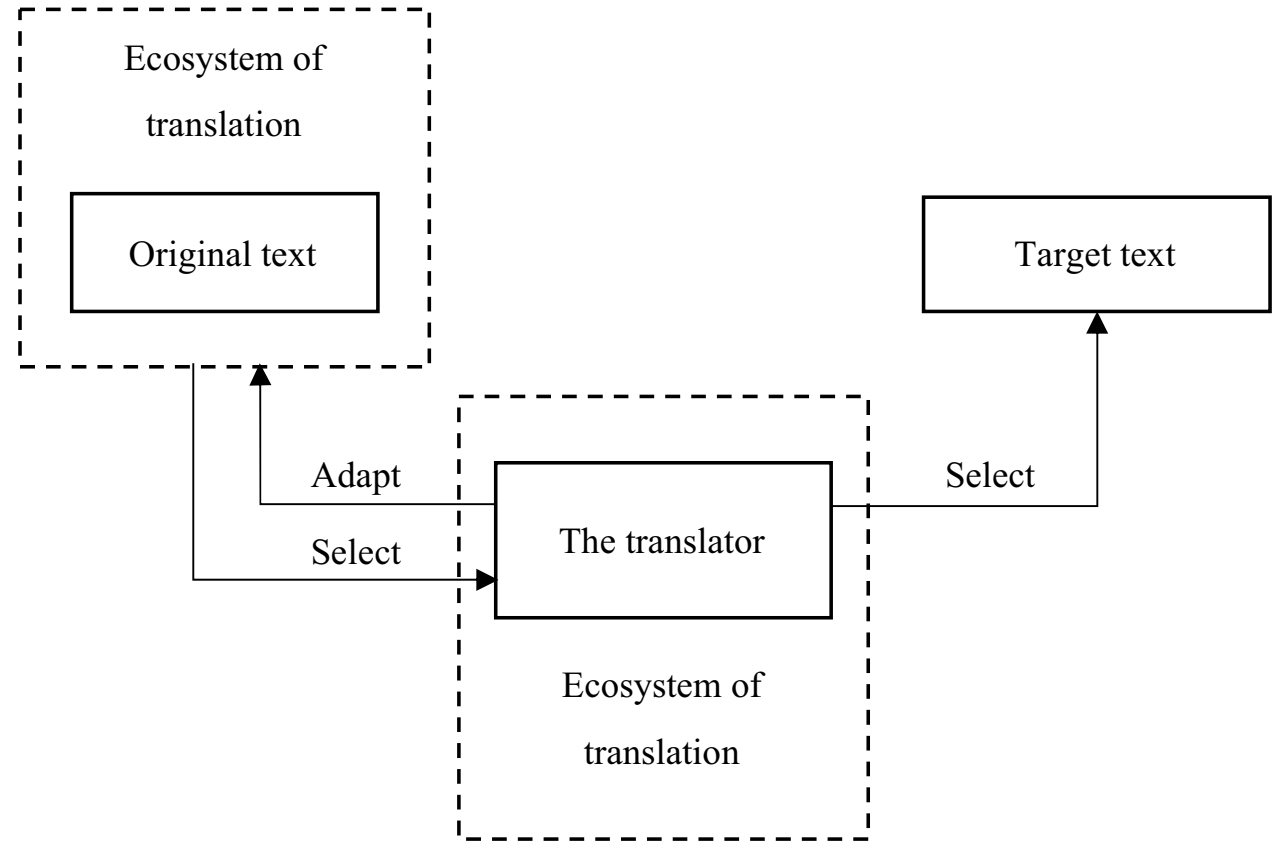

describes Eco-translatology as an interdisciplinary study of Eco-translation, text ecology and 'translation participants'. By 'translation participants', he means a group related to each other through the eco-environment and personal transactions.

According to the translation methods of Eco-translatology, 'how to translate' is a rather complicated issue, as it contains various factors like text type, translation purpose, register (vocabulary), the degree of adaptation and selection. In his approach, a three-dimensional transformation is conducted: (1) the adaptative and selective transformation from the aspect of linguistics; (2) the adaptive and selective transformation from the aspect of culture; (3) the adaptative and selective transformation from the aspect of communication. Thus, Hu (2003) defines the three-dimensional transformation as the adaptative and selective transformation from the aspect of linguistics, and determines the translator should make a reasonable transformation of the language according to the specific translation environment which includes such matters as language structure, collocation, writing style, tone and rhetoric. The adaptative and selective transformation from the aspect of culture means the translator needs to transform the cultural connotation of the source language (SL) to the TL in such a way as to avoid misunderstanding. Therefore, he intends when translators transform the ST, they should focus on the whole intercultural system. Finally, the adaptative and selective transformation from the aspect of communication means the translator should objectively and accurately reflect the original author's information intention, so as to achieve the purpose of that communication. Therefore, the quality of the levels of the three-dimensional system is one of the most significant ways to measure the quality of translation. In other words, the better the translator adapts each aspect of translation, the higher the degree of overall translation excellence.

The use of this theory in this research inspires translation of geotourism data by principal idea, text type and translation methods. In terms of principal idea, this study aims to translate Chinese UNESCO Global Geoparks' brochures, pamphlets, interpretive panels, signs, display boards and museum displays, which are directly tied to the environment. The special reason for using geoparks is that they contain millions of years of natural geological change and evolution as well as rich CEs. Therefore, geoparks need more attention and protection than other ordinary parks. However, one of the problems encountered in the global promotion of Chinese UNESCO geoparks is the lack of interpretation depth in translation. The application of Eco-translatology can improve each translation in detail. Moreover, Eco-translatology has a theoretical foundation shaped on ecological holism, the belief that translation is a holistic, systematic and harmonious system. In such a scenario, the principal idea of the theory is to respect the balance of people and nature. Scholars using Eco-translatology are concerned with the ecological balance in translation. For instance, Rabassa (1989) proposes translation is like life because a literary work rendered from one language to another is like a plant or animal relocated which can live only if it completely adapts to its new environment. Hence, the Eco-translatology and the translation of brochures, pamphlets, interpretive panels, signs, display boards and museum displays in geoparks are complementary from the perspective of principal idea. Guided by Eco-translatology, translators can seek the main basis for the translation of brochures, pamphlets, interpretive panels, signs, display boards and museum displays in geoparks and better understand the special functions of these in geoparks. 
The use of this theory in terms of text type would apply to brochures, pamphlets, interpretive panels, signs, display boards and museums. Museum displays in geoparks can be found at geopark entrances and visitor centres and attract more importance compared to other tourist texts. All the texts contain many geological phenomena (GFs and GPs) and local CEs. This means translators need to interpret the contents to geovisitors in detail, clearly and accurately. In this way, GFs, GPs and CEs can be appreciated by geotourists and geoscientists. Certain recommendations have been made to improve the standardisation of text. Firstly, the content of those translation works in geoparks needs to be comprehensive to include knowledge of geological (GP and GF) and CE (religion, history and arts). This means the TT should achieve semantic equivalence, style equivalence and cultural equivalence. Thus, the Chinese to English translation of geoparks should be one of the most systematic translations. Furthermore, translation in geoparks should be practical, appealing to geotourists, not to scholars or senior managers of parks or government officials. It is important to emphasise that geovisitors include foreign visitors as well as Chinese visitors. For foreign geotourists, they can observe the formation of GFs and experience Chinese cultures from the TT. Poor translations are potentially misguiding and can have a negative influence on the study of English by students. Hence, translation in geoparks is important for overseas geotourists, Chinese-English learners and geoacademics. Therefore, from a text type standpoint, Eco-translatology can be used as a theoretical framework to guide translations in geoparks. Using the theory, text type should transmit basic information, convey the internal cultural connotation and conclude the communicative process. Guided by this theory, translators will place a greater emphasis on the environment in which the ST and TT exist. Additionally, with the use of this theory, translators gain a better understanding of the translation environment in which they work their own roles within it, that is decision maker for each word and expression, creator of a near-perfect translation to adapt various types of original texts and bridge for transmitting culture to different countries or areas. Being conscious of such responsibilities, translators will develop a feeling of mission and accountability. In comparison to viewing themselves solely as 'language tools', the theory can help translators develop their self-awareness and self-identification. In that instance, the translation performance will very probably be superior than what it was previously.

The use of this theory in terms of translation methods means translation activities should be carried out from three dimensions: language, communication and culture. To better facilitate comprehension of various functions of diverse texts, all brochures, pamphlets, interpretive panels, signs, display boards and museum displays in geoparks collected in the investigation are classified and analysed from a pragmatic perspective: offering geotourists geological information, spreading Chinese geological knowledge and unique culture to foreign geotourists, stimulating interest and better understanding and appreciation of Earth, and its geoconservation. When rendering a text, translators should first determine what type the text belongs to. After establishing its kind and function, translators should decide on the dimension to use in the translation activity. For linguistic text whose main task is to convey geological information (GF and GP) to geovisitors, translators should focus on accuracy, detail and language style which should follow semantic equivalence and guarantee style equivalence of TT. Therefore, in linguistic dimension, translation issues mainly focus on UCPREW, language style (short and long; passive voice and active voice; simple and complex). For cultural texts, they may contain numerous cultural components and background; translators should not only consider the accuracy of literal information, but also achieve cultural equivalence which means translator should ensure that foreign readers completely understand cultural information or, at the very least, have a rough idea of the meaning of some cultural terms. Therefore, in cultural dimension, translation problems are UCPREW, Mistranslated, NT and ITSN. For communicative texts, more attention should be paid to geotourists' reaction to the translation. Geotourists in accepting the content should reach the same understanding as in the ST effecting a better understanding and appreciation of Earth, and its geoconservation. Thus, in communicative dimension, translation problems of NT, Mistranslated and ITSN will be solved. As can be seen, the three dimensions of Eco-translatology (principle idea, text type and translation method) can carry out effective translation activities for various types of geotourism texts.

Without the guidance of Hu's Eco-translatology, the application of traditional translation methods has led to many instances of inaccuracy, confusion and inconsistency, in GF, GP and CE geotourism translation. For example, ' 老黑山' is a GF in Wudalianchi UNESCO Global Geopark which was formed by volcanic eruption. There are two translated versions of it which are 'Laoheishan Mountain' and 'Laoheishan'. However, according to the linguistics and communicative dimension of Eco-translatology, if translators rendered it into 'Laoheishan', for foreign geotourists, they will miss the understanding that a mountain was formed. 'Laoheishan Mountain' is an appropriate choice, because it can make overseas geotourists immediately realise the object of this GF is the 'Mountain'. This translation strategy, TF trans, not only achieves semantic equivalence in principles of geotourism translation, but also finishes the transformation of language and communication dimensions. Another example is the formation process (GP) of Mount Huangshan UNESCO Global Geopark, “随着地壳的间歇 抬升, 地下岩体及其上的盖层遭受风化、剥蚀, 同时也 
受到来自不同方向的各种地应力的作用, 在岩体中有产 生出不同方向的节理' which was rendered into 'With the sporadic uplift of the earth's crust, the underground rock mass and its caprock undergo weathering and denudation, and are also affected by various in-situ stresses from different directions, resulting in fractures in different directions in the rock mass'. This translation does not conform to the English style of using clear, simple short sentences and passive voice. Therefore, it cannot be an effective way to communicate geological information to foreigners and to achieve the equivalence of English and Chinese language styles. Using Eco-translatology principles, DS trans was generated to solve the style equivalence. Therefore, this GP should be translated into 'As the crust was intermittently uplifted, both rock formations underground and those on the surface suffered weathering and erosion. At the same time, they were affected by various tectonic stresses from different directions, resulting in the formation of geological jointings going in different directions'. A further example is the CE in Taishan UNESCO Global Geopark; ‘元君庙’ was rendered into 'Yuanjun Temple.' This word-by-word translation has lost its cultural connotation. '元君', in Taoist culture, is the goddess who guards Mount Tai. Thus, the use of free translation strategy to render it into 'Taoism Goddess Temple' was more accurate. This TT achieves cultural equivalence by completing the transformation of cultural and communication dimensions based on Hu's Eco-translatology. Hence, the use of Eco-translatology is most effective. GFs, GPs and CEs will be analysed and translation strategies will be generated based on Eco-translatology in detail in the 'Results and Discussion' section.

The purpose of this research is to improve the TT by using a combination of corpus linguistics and Eco-translatology. Firstly, after a quantitative and qualitative analysis is performed, the translation problems, annotated into three categories (GFs, GPs and CEs), respectively, were retrieved in concordance. The function formula should be put in the PARALLEL CONCORDANCE page as below:

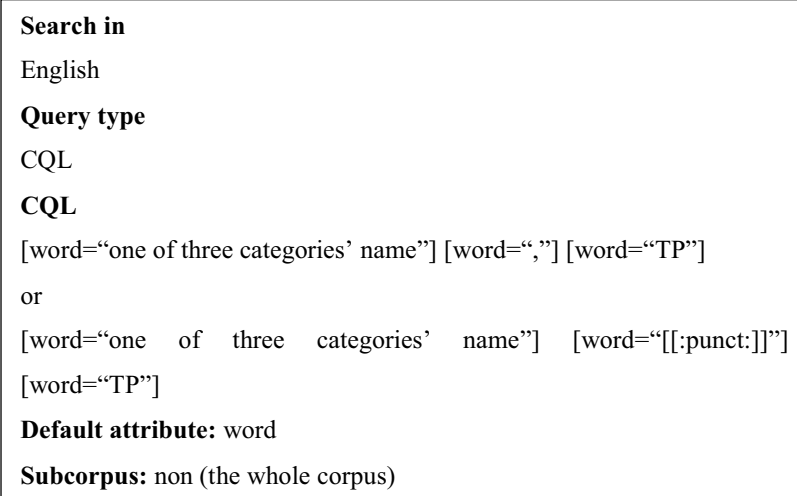

Secondly in the research method, through extensive concordance in the PGC, the specific translation problems (UCPREW, Mistranslated, NT and ITSN) of the three categories (GFs, GPs, CEs) were found and annotated accordingly. Thirdly, according to the definition and principles of three dimensions of Eco-translatology, these four translation problems were classified into the three dimensions (linguistics, cultural and communicative). Fourthly, through a smallscale concordance, translation problems of each category were counted and shown in a bar chart. The function formula should be put at the PARALLEL CONCORDANCE page as below:

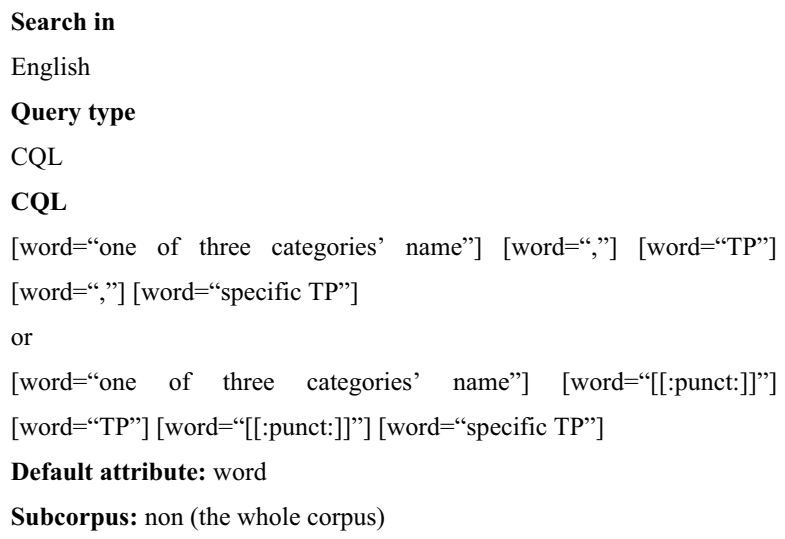

Fifthly, translation problems of each category were improved through developing new effective strategies. Finally, translation problems of the three categories (GFs, GPs and CEs) and the corresponding translation strategies were summarised based on the Hu's Eco-translatology theory, an operating model shaped and recommendations made.

\section{Results and Discussion}

\section{Translation Strategies and Improvements in GFs}

After retrieving the PGC, the different translation strategies used in GFs were counted in order to conduct the quantitative and qualitative analyses. An extensive concordance was compiled on the PGC through function formula: [word = "GF"] [word = ","] [word = "TS"]. The frequency total of applied translation strategies in GFs was found after analysis to be 422 including literal translation, transliteration and free translation, shift and addition. After this quantitative analysis, the types of translation strategies mentioned in the previous sentence above were retrieved in the PGC respectively through function formula: [word = "GF"] [word = ","] [word = "TS"] [word = ","] [word = "specific 
Fig. 6 Applied translation strategies in GFs

\begin{tabular}{ccc}
\hline Translation strategies & Frequency & Percentage \\
\hline Literal Trans & 325 & $77.02 \%$ \\
TF Trans & 88 & $20.85 \%$ \\
Foreignisation & 1 & $0.24 \%$ \\
Addition & 5 & $1.18 \%$ \\
Shift & 3 & $0.71 \%$ \\
Total number & 422 & $100 \%$ \\
\hline
\end{tabular}

TS"]. The specific statistics found are listed in Fig. 6 and by bar chart in Fig. 7.

The table and bar chart show the frequency and percentage of applying translation strategies in GFs. Firstly, the complexities of the literal translation category will be examined. When translators rendered GFs, as expected, literal translation (77.02\%) is by far the most frequently used, followed by transliteration and free translation (20.85\%) which is about four times less but still of some comparative significance. It was seen through parallel concordance in the PGC that translators use straightforward literal translation when they deal with two types of occurrences of GF jargon. The first occurrence is if the geological terms of semantic equivalence can be found between English and Chinese. For example, ‘节理' was translated into 'joint' and “火山岩” was translated into 'volcanic rocks'. The second occurrence is with names of some caves, rocks or peaks that relate to a specific shape. For example, ‘孔雀峰' was translated into 'Peacock Peak', because the upright peak looks like a peacock. Similarly,
“鱼骨岩' was translated into 'Fish Bone Rock' as the rock has a fish bone shape. Literal translation is the optimum if possible, through equivalence, as it enables foreigners to appreciate the identification of the rock as a likeness to a particular animal. In this case, literal translation is like a simple mirror image which only requires equivalent linguistics.

However, literal translation cannot be applied for all the GF items. When translators deal with the translation of some names of rocks, caves and peaks that relate to specific cultural knowledge in SL, transliteration and free translation need to be adapted. For example, ‘独秀峰' was rendered into 'Duxiu Peak'. It is clear that the translation of “独秀峰' is the combination of Chinese Pinyin 'Duxiu' and the translated GF 'peak'. '独秀(Duxiu)' is a specific Chinese cultural word, which has no equivalent word in English. In this case, the transliteration and free translation strategy takes into account the difference between Chinese and Western cultures. Therefore, the first half of the Chinese characters was translated by transliteration (keeping the Chinese Pinyin
Fig. 7 Percentage of translation strategies applied in GFs

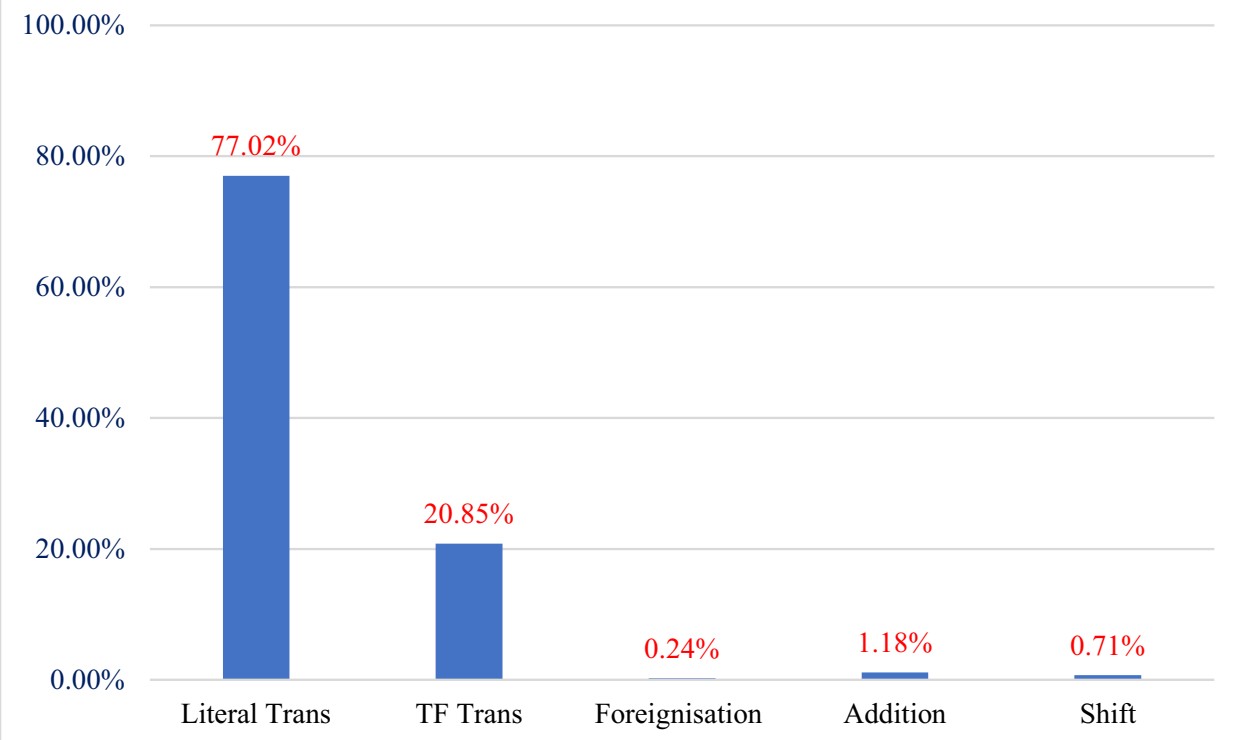


part), while the latter part of the Chinese characters was rendered by free translation to know what kind of shape the GF is. Thus, part of the TT retains the meaning of the GF, and the other part, the similar pronunciation but neither part uses literal translation. It is worth mentioning that the use of transliteration and free translation strategy in the PGC (20.85\%) all comes from the translation of the names of caves, rocks and peaks.

Another type of example also shows the complexity of literal translation; the translators used the literal translation to render four-Chinese-character cultural structures which are related to GFs. This kind of GF was formed by GP such as weathering, water erosion and volcanic eruption. For example, ‘崇山峻岭、险㱡幽谷’ was translated into 'lofty, precipitous mountain ranges, deep and serene valleys' and '奇 峰叠障、怪石飞瀑' was rendered into 'fantastic landscapes of rocks, peaks and waterfalls' in the PGC. Therefore, these four-Chinese-character cultural structures were interpreted to geotourists by using elegant language through literal translation. In this case, it was helpful for them to capture the dramatic feelings of the landscape in the geoparks and geomuseums. These various examples of translation strategy demonstrate the complexity of literal translation by following the framework of the three-dimensional transformation of Eco-translatology.

The remaining three categories of applied translation strategies, foreignisation, addition and shift, account for such a small proportion that they can be defined as exceptional. The percentage of foreignisation, addition and shift is less than $3 \%$. This means the frequency of addition, foreignisation and shift in this PGC is negligible but at times necessary. Since there are great differences between Chinese and English grammar and style, it is at times important to add explanation of the original text information in order to effectively convey the desired meaning to the geotourists. For an example, the typical addition strategies applied in the PGC are as follows:

ST 1: $<\mathrm{s}>$ 抗风化能力弱的凹陷处成了 '田, 反之凸出 处成了“埂”。</s $>$

TT 1: $<$ s $>$ The less resistant parts become 'fields' $<$ GF, TS, Literal Trans $>$ and the more resistant parts become 'banks' (the low banks of earth between fields) $<$ GF, TS, Addition $><$ GP, TS, Division $>.</ \mathrm{s}>$

In the above case, addition was adopted to translate '埂' in order to make up for the lack of information at the cultural level to make the TT more meaningful to the foreign tourist. This strategy aligns with the transformational cultural dimension of eco-translatology. When '田' and '埂' are combined into '田埂', the translator applied foreignisation to render it into 'traditional Chinese paddy fields'. This is because traditionally Chinese farmers have cultivated rice in '田埂'. In another minor category, shift, an example can be found when a part of speech conversion is used in the PGC.
ST 2: < s > 岩石表面纹路纵横交错,形似 ‘田埂”,故民间 称之为 “仙人造田”。 $</ \mathrm{s}>$

TT 2: $<\mathrm{s}>$ The rock $<\mathrm{GF}$, TS, Literal Trans $>$ has crisscrossing lines on the surface, which look like traditional Chinese paddy fields $<\mathrm{GF}$, TS, Foreignisation $>.</ s><s>$ That is why locals call it 'Divinely Crafted Farmland' $<$ GF, TS, Shift $>.</ s>$

In this example, the translator rendered '仙人造田' into 'Divinely Crafted Farmland'. In Chinese, ‘仙人' is similar to 'god' in English culture, and refers to a person in mythology or traditional tales who is powerful and immortal. The translator transformed the noun ('仙人') into an adverb ('Divinely') during the translation process. The translation is not only adapted, but also becomes an integral part of the recipient's culture. This is again in line with the transformation of linguistic and cultural dimensions in Eco-translatology.

In regard to translation problems (TPs), in principle, the PGC was compiled by extensive concordance through function formula: [word= "GF"] [word = ","] [word = "TP"] The total frequency of translation problems in GF was 329 including the categories of UCPREW, Mistranslated, NT and ITSN. After establishing this initial quantitative analysis, the translation categories mentioned above were retrieved respectively in the PGC through function formula: [word = "GF"] [word = ","] [ word = "TP"] [ word = ","] [word = "specific TP"]. The specific statistics resulting are shown in Fig. 8 and in bar chart in Fig. 9.

The table and bar chart illustrate the frequency and percentage of translation problems in GFs. ITSN accounts by far for the largest percentage (93.31\%) among these four problems. Coincidentally, UCPREW and Mistranslated share the same proportion, both minutes, at $3.04 \%$. NT accounts for the least, less $1 \%$. Using the search through parallel concordance, quantitative analysis reveals these four translation problems are related to translation of the names of peaks, caves, rocks, rivers and waterfalls.

To look more closely at the problems of translation in the PGC, examples of ITSN and Mistranslated can be selected to illustrate the challenges of geotourism translation. Firstly, '大龙湫', in the PGC, has been translated into three different versions which are 'Big Dragon Waterfall', 'Giant Dragon Waterfall' and 'Dalongqiu'. The second term, '小 龙湫', was rendered into 'Small Dragon Waterfall' which is categorised as Mistranslated. In traditional Chinese values, 'dragon' is the symbol of power, wealth and auspiciousness, and traditionally the Chinese nation is considered 'the descendants of the dragon'. The emperor of all historical dynasties in China is also known as the true son of the dragon'. However, in the West, in traditional tales such as Saint George and the dragon, the 'dragon' is symbol of evil, is possessive and physically portrayed as a fierce and cruel monster. Translation is a cross-cultural activity; the TT can 
Fig. 8 Translation problems in GFs

\begin{tabular}{ccc}
\hline Translation problems & Frequency & Percentage \\
\hline UCPREW & 10 & $3.16 \%$ \\
Mistranslated & 10 & $3.16 \%$ \\
NT & 2 & $0.64 \%$ \\
ITSN & 307 & $93.31 \%$ \\
Total number & 329 & $100 \%$ \\
\hline
\end{tabular}

be literally translated but then becomes completely divorced from the original meaning out of the context of the original cultural background. If '龙' was translated into 'dragon', it would cause misunderstanding among foreign geotourists in the sense of intimating a negative or threatening quality to the waterfall which is not in the original text at all. The waterfall's name is intended to cause admiration. Therefore, if a positive outcome is intended by the translation, 'dragon' cannot appear in the TT. As discussed above, there are two main strategies translators often adopt (literal translation, and transliteration and free translation). To translate these particular cultural GF terms, the transliteration and free translation strategy was recommended. In this way, '大龙' and '小龙' can be translated into 'Dalong' and 'Xiaolong'. In these two GF examples, the size of the '湫' is different. The transliteration of cultural function words 'Dalong' and 'Xiaolong' will not carry the sense of their respective sizes; thus. the full meaning is weakened in the aspect of size. Therefore, '大龙湫' was simply translated into 'Dalong Waterfall' and '小龙湫' was rendered as 'Xiaolong Pool'. Eco-translatology points out that only the TT translation can survive, so the translator should produce the best adaptation and selection. In this case, much original text meaning does not survive. Moreover, the translations of '丹霞山' and ‘ 昆仑山' are also ITSN in the PGC. ‘丹霞山' was rendered into 'Danxiashan', 'Mount Danxia', 'Danxia Mountain (Red Colored Rocks)' and 'Danxiashan Mountain'. Similarly, ‘昆仑山' was translated into 'Kunlunshan', 'Kunlun Mountain' and 'Mountain Kunlun'. Since the subject of this research is related to UNESCO Global Geoparks, it is significant to check the English UNESCO Website (https://en. unesco.org/2021a) for these official names to avoid confusion in translation. This means the translation of '丹霞 山’ and '昆仑山' is 'Danxiashan' (http://www.unesco.org/ new/en/natural-sciences/environment/earth-sciences/unescoglobal-geoparks/list-of-unesco-global-geoparks/china/danxi ashan/ 2021b) and 'Mount Kunlun' (http://www.unesco. org/new/en/natural-sciences/environment/earth-sciences/ unesco-global-geoparks/list-of-unesco-global-geoparks/ china/mount-kunlun/ 2021c). These are the official names used by UNESCO.

Another problem is that sometimes there is no corresponding vocabulary in English to convey the culture-specific meaning in Chinese, so translators face a challenge and will render GF
Fig. 9 Percentage of translation problems in GFs

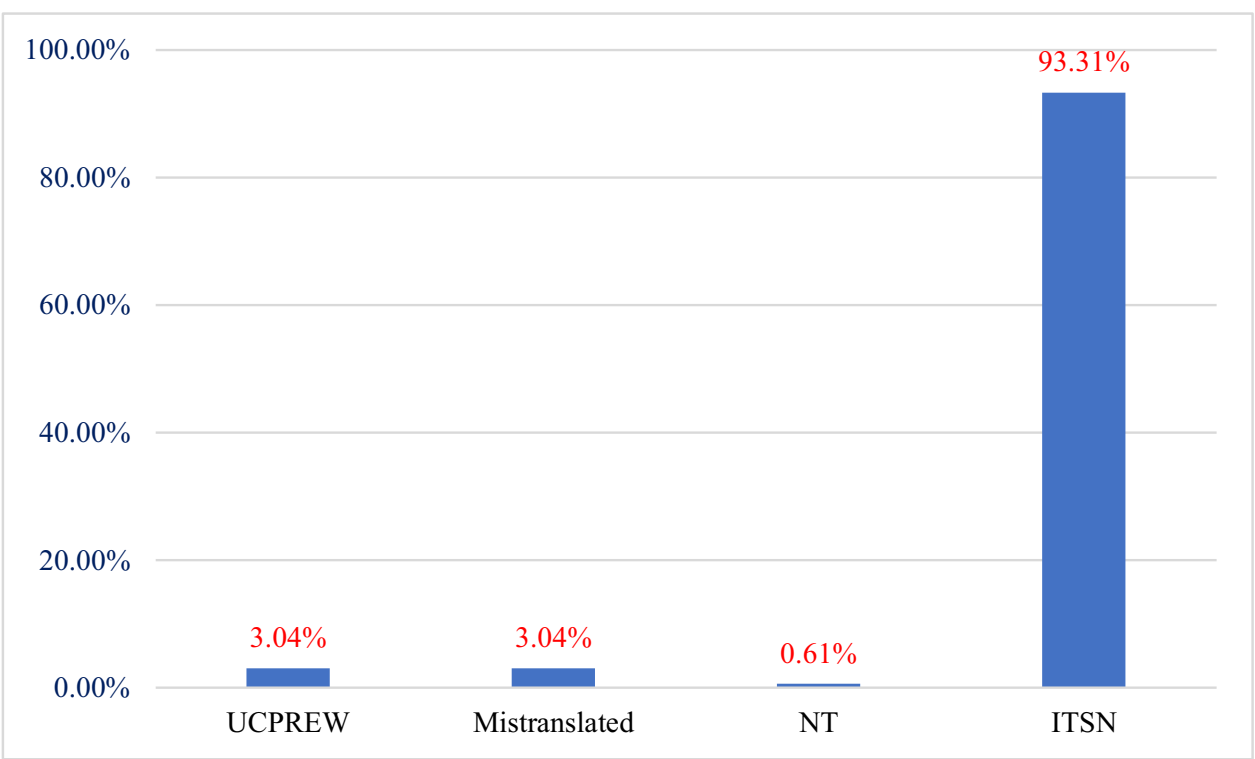


Fig. 10 Typical examples of translation problems in GFs

\begin{tabular}{cccc}
\hline Text & ST & TT & Translation Problems \\
\hline $\mathbf{3}$ & 金鞭岩 & Jinbianyan & UCPREW \\
$\mathbf{4}$ & 雄鹰展翅 & Eagle & NT \\
$\mathbf{5}$ & 海贝听涛 & Shells & NT \\
\hline
\end{tabular}

terms poorly which are labelled as UCPREW, or NT. Some typical examples in the PGC are shown in Fig. 10.

Direct translation such as ‘雄鹰展翅 (Eagle)', ‘海贝听涛 (Shell Rocks)', and 金鞭岩' in PGC failed to communicate or offered meaningless target cultural terms. When the rocks reflect their own shape, literal translation would be used. For example, “雄鹰展翅' is recommended to be rendered 'Eagle Rocks'. The word '雄鹰展翅' here mainly involves the shape of the rock, and the shape of the rock resembles an eagle spreading its wings. Similarly, “海贝听涛” was recommended to be translated into 'Horizontal Seashell Rocks'. The word '海贝' refers to the shape of the rock that looks like a shell. After a GP (water erosion), the rock was shaped like a shell scattered on the beach; some metaphorical meaning of the original is lost however because the Chinese hints that the ear-shaped rock is listening to the wave. Another complex example of problems in translation can be found in '金鞭岩'. It can be revised into 'Golden Whip Rocks'. However, the '金' here is not the colour of the rock, but the colour of the sunshine on the rock. '鞭' is translated into 'whip' as those rocks look like whips. The strategies here give revised versions which achieve an improved result through the Eco-translatology transformation of linguistics, culture and communication.

As a result of analyses and Eco-translatology framework, three main translation strategies (literal translation, transliteration and free translation, free translation and addition) can be identified and recommended for translating GF jargon. Fig. 11 summarises and clearly demonstrates the successful strategies and some corresponding examples. Exceptionally, in addition, two minor translation strategies (foreignisation and shift) will be considered if the above four cannot be used, such as in Texts 1 and 2. This table points to the foundation of a new model for translation problems and corresponding strategies according to the type of geotourism category. Here, it is geological formations (GFs).

\section{Translation Strategies and Improvements in GPs}

Similarly, in order to improve the quantitative and qualitative analysis of GP translation strategies applied in the PGC, the retrieval steps of those in the "Translation Strategies and Improvements in GFs" section were carried out. Thus, the function formula [word = "GP"] [word = ","] [word = "TS"] was used extensively to retrieve targeted GP translations in the PGC. The total frequency of translation strategies in the GP category was 623; the four specific strategies were DS Trans, division, Literal Trans and Shift. These four translation strategies were next retrieved by their category respectively, through the function formula: [word= "GP"] [word = ","] [word = "TS"] [word = ","] [word = "specific TP"]. The resulting percentage rate of each applied translation strategy is illustrated in Fig. 12 and by bar chart in Fig. 13.

Literal translation accounts for the largest proportion. Notably, division and shift are so small as to count as exceptional in their use, less than $1 \%$ and $2.90 \%$, respectively. In the next process, some typical GP examples, in all four translation categories, were analysed. Firstly, translations in the category via Literal Trans can be demonstrated by Texts 6 and 7. They are a phrase and collocation that directly corresponds with English. (Most of the GP Literal Trans are like this.) These translations below show that GP phrases in Chinese can find direct semantic equivalents in English.

ST 6: $<\mathrm{s}>$ 河流侧蚀作用 $</ \mathrm{s}>$

TT 6: $<\mathrm{s}>$ Lateral Erosion by Rivers $<$ GP, TS, Literal Trans $></ \mathrm{s}>$

ST 7: $<s>$ 河蚀作用的方向分为溯源侵蚀、下蚀、侧 蚀。 $</ \mathrm{s}>$

TT 7: $<\mathrm{s}>$ The direction of fluvial erosion $<$ GP, TS, Literal Trans $>$ includes headward erosion $<$ GP, TS, Literal Trans $>$, down-cutting $<$ GP, TS, Literal Trans $>$, and lateral erosion $<$ GP, TS, Literal Trans $>.</ \mathrm{s}>$

There were two (Text 8 and 9) translations in the PGC that were slightly different in this category and they were sentences describing geological formation. A feature of this kind of GP is that it does not include implicit and explicit passive verbs and is simple and short. They are literally translated which not only retains the language style of the ST, but also makes the TT concise and intelligible.

ST 8: $<\mathrm{s}>$ 这块岩石比较靠近山边, 受流水冲刷的力 度较小而残留下来, 最终形成石门槛。</s $>$

TT 8: $<\mathrm{s}>$ The boulder $<$ GF, TS, Literal Trans $>$ is close to the hill and subject to weaker fluvial action $<$ GP, TS, Literal Trans $>$ and eventually forming a stone gate $<$ GF, TS, Literal Trans $>.</ s>$ 
Fig. 11 Taxonomy of translation strategies in GFs

\begin{tabular}{|c|c|}
\hline Translation strategies & Categories in GFs \\
\hline \multirow[t]{3}{*}{ Literal translation } & $\begin{array}{l}\text { (1) When translating some GF jargon corresponding equivalent } \\
\text { words in English can be found, such as '熔结凝灰岩' --- 'welded } \\
\text { tuff'. }\end{array}$ \\
\hline & $\begin{array}{l}\text { (2) When translating some names of rocks, caves, peaks, and } \\
\text { waterfalls equivalent nouns which reflect their shapes can be used, } \\
\text { such as '象岩' --- 'Elephant Cliff'. }\end{array}$ \\
\hline & $\begin{array}{l}\text { (3) When translating Chinese-four-character structures of GF, } \\
\text { equivalent descriptive words can be used such as '险壑幽谷' --- } \\
\text { 'deep and serene valleys'. }\end{array}$ \\
\hline Transliteration and free translation & $\begin{array}{l}\text { When translating some names of rocks, caves, peaks, and waterfalls, } \\
\text { direct translation cannot reflect their name/s meaningfully. So the } \\
\text { former part (cultural function characters) can be used with } \\
\text { transliteration and the latter part rendered by free translation, } \\
\text { resulting in an example such as '石戟洞' --- 'Shiji Cave'. }\end{array}$ \\
\hline Addition & $\begin{array}{l}\text { When translating GF jargon in which there are cultural blocks to } \\
\text { direct translation, the cultural difference will prevent the literal } \\
\text { meaning and so approximate descriptive terms can be added, such } \\
\text { as '埂' ---'banks (the low banks of earth between fields)'. }\end{array}$ \\
\hline Official name used by UNESCO & $\begin{array}{l}\text { When translating some GFs which are official names, these names } \\
\text { were recognised as already available in the UNESCO Global } \\
\text { Geoparks, such as '丹霞山' --- 'Danxiashan' and '昆仑山' --- } \\
\text { 'Mount Kunlun'. }\end{array}$ \\
\hline Foreignisation & $\begin{array}{l}\text { As exceptional examples and not part of the pattern, foreignisation } \\
\text { strategies occurred once only in the PGC such as '田埂' --- } \\
\text { 'traditional Chinese paddy fields' in Text } 2 \text {. Shift strategies only } \\
\text { occurred three times in the PGC such as '仙人造田' --- 'Divinely } \\
\text { Crafted Farmland' in Text } 1 \text {. }\end{array}$ \\
\hline
\end{tabular}

ST 9: $<s>$ 其形态是流纹岩断裂、风化剥落塑造而成 的。 $</ \mathrm{s}>$

TT 9: $<\mathrm{s}>$ The spectacular shape came into being as a result of faulting $<\mathrm{GP}$, TS, Literal Trans $>$ and weathering $<$ GP, TS, Literal Trans $>.</ s>$

The three translation strategies of shift, division and DS Trans can be demonstrated and are found to be mainly used in the formation of GFs. The language in translation is altered at syntactic level. Texts 10 and 11 show the Shift category. The keywords are underlined.

ST 10: $<s>$ 岩层受到地质作用被拉伸或挤压, 使得岩 层折断形成裂陌, 如果它们发生相对运动, 就形成了断 层。</s $>$
TT 10: $<\mathrm{s}>$ Stretched $<$ GP, TS, Literal Trans $>$ and squeezed $<$ GP, TS, Literal Trans $>$ by geological forces, the rock layers $<\mathrm{GF}$, TS, Literal Trans $>$ fractured, and if any relative movements occurred between them, faults may be formed $<$ GP, TS, Shift $>$. $</ \mathrm{s}>$

ST 11: $<\mathrm{s}>$ 火山以酸性岩浆的爆发占主导地位, 有大 面积的火山碎屑流堆积, 形成熔结凝灰岩、流纹岩、凝 灰岩等火山岩。 $</ \mathrm{s}>$

TT 11: The initial stage was dominated by outflow of acidic magma in form pyroclastic flow which eventually turned into welded tuff $<\mathrm{GF}$, TS, Literal Trans $>$, rhyolite $<$ GF, TS, Literal Trans $>$ and tuff $<$ GF, TS, Literal Trans $><$ GP, TS, Shift $>.</ s>$ 
Fig. 12 Applied translation strategies in GPs

\begin{tabular}{ccc}
\hline Translation strategies & Frequency & Percentage \\
\hline DS Trans & 96 & $15.40 \%$ \\
Division & 2 & $0.32 \%$ \\
Literal Trans & 507 & $81.38 \%$ \\
Shift & 18 & $2.90 \%$ \\
Total number & 623 & $100 \%$
\end{tabular}

Texts 12 and 13 show the division category. In this division category, GPs were interpreted into wordy and convoluted style in the ST. However, it does not conform to the language style of English. In English style, TT should be direct and concise. Texts 12 and 13 are clear examples to reflect this principle.

ST 12: $<\mathrm{s}>$ 流水沿节理裂陌冲刷侵蚀, 并向下汇聚, 冲刷能力越来越强, 宽度变大, 从而形成了下大上小的 空陌。 $</ \mathrm{s}>$

TT 12: $<\mathrm{s}>$ Flowing water scours and erodes the joints $<$ GF, TS, Literal Trans $>$ of the caves $<$ GF, TS, Literal Trans $>$ and converges downward. $</ s\rangle<$ s $>$ Its energy accumulates and the water becomes more powerful to widen the joints $<$ GF, TS, Literal Trans $>$ and gaps to produce a narrow top and wide bottom arrangement $<$ GP, TS, Division $>.</ s>$

ST 13: $<\mathrm{s}>$ 当侵蚀基准面下降时, 因基面下降而出 露的河床坡度增大, 水流侵蚀作用加强, 开始在新出露 的河段发生侵蚀, 然后逐渐向上游发展, 导致溯源侵 蚀。</s $>$
TT 13: $<\mathrm{s}>$ When the erosion $<$ GP, TS, Literal Trans $>$ base level of the river dropped, gradient of river bed increased and thereby erosion enhanced $<$ GP, TS, Literal Trans $>.</ s><$ s $>$ Water started eroding $<$ GF, TS, Literal Trans $>$ the newly exposed surface and gradually receded towards the upstream $<$ GP, TS, Division $>.</$ s $>$

Texts 14 and 15 show the DS Trans category. These text examples show the difference between categories in translation of GPs. As well as the division category mentioned in Texts 14 and 15, these texts also have passive in the TT which may or may not be in the ST explicitly.

ST 14: $<\mathrm{s}>$ 来自地下炽热的岩浆携带岩石碎屑、晶 体碎屑等在快速堆积过程中形成熔结凝灰岩, 被压扁拉 长, 绕过较硬的碎屑, 形成密集平行排列的假流纹构造, 后来又被两组近直立相交的节理分割成无数小块, 酷似 古代铠甲上的鳞片而得名。 $</ \mathrm{s}>$

TT 14: $<\mathrm{s}>$ Underground molten magma carried lapilli and crystallized pyroclastic materials to the surface. $</ \mathrm{s}\rangle<\mathrm{s}>$ They accumulated and cooled $<\mathrm{GP}$, TS, Literal Trans $>$ to form welded tuff $<$ GF, TS, Literal
Fig. 13 Percentage of translation strategies in GPs
$100.00 \%$

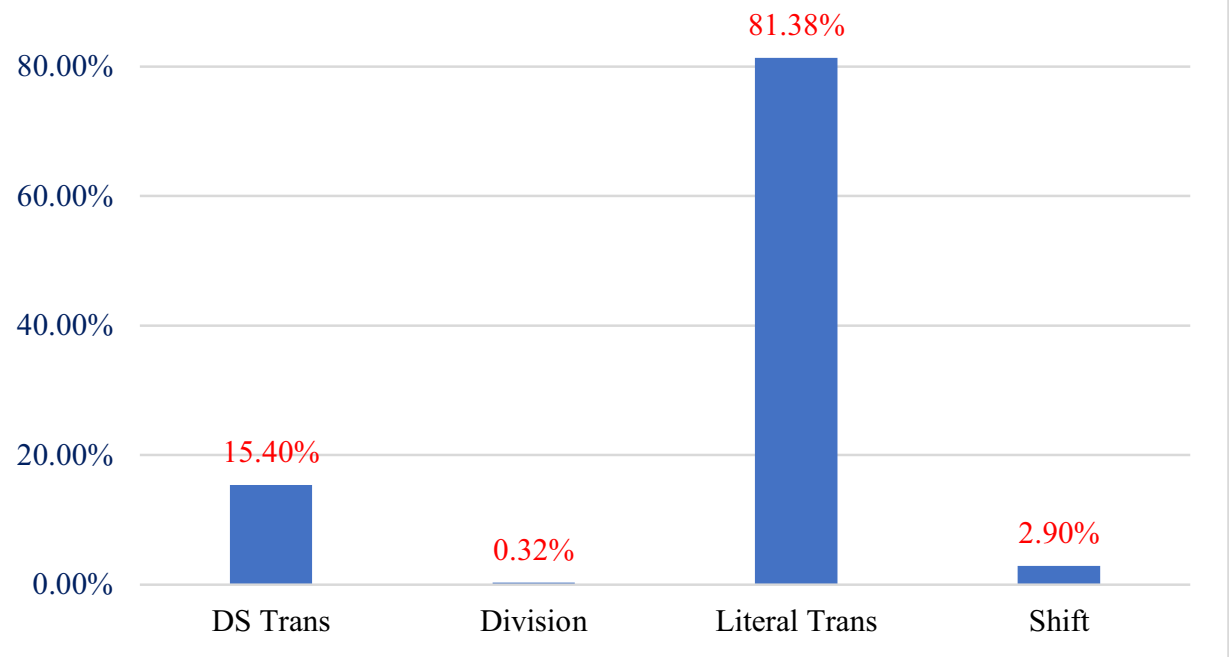


Trans $>.</ s><\mathrm{s}>$ The materials inside the tuff $<\mathrm{GF}$, $\mathrm{TS}$, literal Trans $>$ were pressed $<\mathrm{GP}, \mathrm{TS}$, Literal Trans $>$, stretched $<\mathrm{GP}, \mathrm{TS}$, Literal Trans $>$ and flattened $<\mathrm{GF}$, TS, Literal Trans $>$ to form pseudo-rhyolitic flow structure $<$ GF, TS, Literal Trans $>$. $</ s><s>$ They were finally cut into numerous small pieces by two sets of intersecting joints $<\mathrm{GF}$, TS, Literal Trans $>$ to look like an ancient armor $<$ GP, TS, DS Trans $>$. $</ \mathrm{s}>$

ST 15: $<s>$ 最初的石桅岩是高箃的火山岩台地, 被该 区三组断裂交汇切割形成破碎带, 发生崩塌及流水侵蚀, 由边缘向中心不断风化缩小, 其蚀余残留突出于地表, 形 成桅杆似的柱状孤峰。 $</ s>$

TT 15: $<\mathrm{s}>$ Shiwei Peak $<$ GF, TP, ITSN $>$ was originally a volcanic plateau $<\mathrm{GF}$, TS, Literal Trans $>$. $</ \mathrm{s}><\mathrm{s}>$ The area was then dissected by three sets of fault and created a shattered zone. $</ s\rangle<\mathrm{s}>$ The shattered zone gradually eroded $<$ GF, TS, Literal Trans $>$ by weathering $<\mathrm{GF}$, TS, Literal Trans $>$ and fluvial erosion $<\mathrm{GF}$, TS, Literal Trans $>$ to form a mast-like peak $<\mathrm{GF}$, TS, Literal

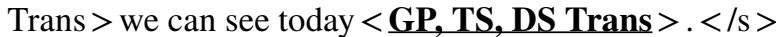

It is appropriate at this point to again demonstrate the structural and cultural linguistic differences between Chinese and English. According to Xiao et al. (2006), Chinese and English have different habits of expression. Passive voice is used quite routinely in English but is not always counted necessary for use in Chinese but intended instead to be understood by the listener. Therefore, it is necessary to carry out this conversion (Voice Shift-Shift category) in Chinese-English translation. In Text 11, there is an implicit passive '占主导地位' in the ST which was translated into 'was dominated by' in the TT. In contrast, Texts 10, 14 and 15 include an explicit passive marker '被 (bèi)' in Chinese which was translated into the passive form in English.

Another major difference in English is the need to break up a long sentence. Xiao et al. (2006) point out that in English, a long complex sentence is often divided into many clauses or phrases with necessary punctuation. This means complicated GPs in Chinese do not match English style. To compensate for this difference, division strategy is used in translation into English. Division is used in Texts 14 and 15. In a more complex example, in Texts 12 and 13 which previously demonstrated division, there are two further remarkable features in their STs. These GPs both have a complicated process and active narration, no passive markers. Translators generally only use division with active voice but it is necessary in these two Texts 12 and 13, to use a different strategy (DS Trans). Therefore, the ST needs radical linguistic changes for successful translation which again confirms Hu's (2001) theory of Eco-translatology. Thus, this is a good example of the theory where the translator must override the linguistic barriers to build wholistic meaning in the TL. In this case, it is by the use of DS Trans strategy for GP category.
As GPs contain technically complex subject matter, there are scientific terms difficult for translators to understand, because they lack specific expertise leading to problems in translating. This could result in categories like NT and Mistranslated. The function formula [word = "GP"] [word = ","] [word = "TP"] was used to retrieve these throughout the whole PGC. There was only NT, and the frequency of NT was 24 . This implies that the translator's habit was to ignore the difficulty and omit any reference to it. Eco-translatology was used to guide the improvement of these omissions. Two examples are analysed as below:

ST 16: < s > 仔细观察对岸河流与山崖的交汇处, 山崖 底部向内凹陷, 它是由于湍急的河流以自身的动力及挟 带的砂石对山体进行破坏侵蚀而形成的。 $</ s>$

TT 16: $<\mathrm{s}>$ The concave part of the cliff $<$ GF, TS, Literal Trans $>$ along the river is subject to continual undercutting by water which carried abrasive sand and gravel $<\mathrm{GP}$, TP, NT $>.</ \mathrm{s}>$

ST 17: $<s>$ 约1亿年前, 火山喷出的岩浆冷却后形成火 山岩, 厚度巨大的火山岩受断裂影响, 加之流水侵蚀导致 岩石不断崩落后退, 最终造就了石桅岩的雄伟气势和独 特的地质地貌景观。 $</ \mathrm{s}>$

TT 17: $<$ s $>$ About 100 million years ago, lava from volcanoes $<$ GF, TS, Literal Trans $>$ flowed $<$ GP, TS, Literal Trans $>$ and cooled $<$ GP, TS, Literal Trans $>$ to form rocks $<$ GF, TP, ITSN $>.</ \mathrm{s}><\mathrm{s}>$ They were later eroded $<$ GP, TS, Literal Trans $>$ and collapsed $<$ GP, TS, Literal Trans $>$ to form the grand and unique looking Shiwei Peak $<$ GF, TP, ITSN $><$ GP, TP, NT $>$. $</$ s $>$

In the above two examples, the missing translation is in bold. These omissions would understate the process and leave the reader ignorant. According to the linguistic and communicative dimensions of Eco-translatology, the example of Text 16 was rendered:

'Close observation of the cliff, where it meets the river, shows the cliff collapsing inward from erosion by sand and stones carried by the turbulent river'.

The translator has added shift strategy (shift) to make the translation more concise. Similarly, the translator also used DS Trans to supplement and improve Text 17, rendered:

'About 100 million years ago, lava erupted from the volcano cooled, and formed volcanic rocks. The very thick volcanic rocks were faulted, and subject to water erosion over time, caused them to collaspe. Finally, through these immense geological forces the unique geomorphic landscape of the magnificent Shiwei Peak was created'.

This version makes this GP complete, more logical and the GP more vivid. Thus, through quantitative and qualitative analysis and Eco-translatology, four translation strategies (DS Trans, Division, Literal Trans and Shift) can be 
Fig. 14 Taxonomy of translation strategies in GPs

\begin{tabular}{ll}
\hline Translation strategies & \multicolumn{1}{c}{ Categories in GPs } \\
\hline DS Trans & When GPs are complex long sentences they are be divided into \\
many simple clauses or sentences. When GPs contain explicit and \\
implicit passive structure, passive voice is to be used in the sub- \\
clause, Texts 14 and 15. \\
(1) Translating GP jargon in GPs, such as Texts 6 and 7 \\
(2) Translating sentences of GPs without implicit and explicit \\
expressions in the ST and the GPs were simple and short in the ST, \\
such as Texts 8 and 9. \\
When GPs are simple short sentences and contain explicit and \\
implicit passive structure, passive voice was used in translating GP, \\
such as Texts 10 and 11. \\
Shift \\
When GPs are complex long sentences and do not contain explicit \\
and implicit passive structure, long sentences are be divided into \\
many simple sentences, and active voice was used in the sub-clause, \\
such as Texts 12 and 13.
\end{tabular}

identified, and added to the model for geotourism translation. Fig. 14 summarises and clearly demonstrates the successful strategies and corresponding examples recommended for GP category translation.

\section{Translation Strategies and Improvements in CEs}

To address the cultural translation problems (CEs), a similar process was followed: the function formula [word = "CE"] [word = ","] [word = "TS"], to retrieve the frequency and character of CEs. Through parallel concordance, the total frequency of translation strategies in CEs was 433 and the types of strategies were TF Trans, Free Trans, Addition and Literal Trans. Furthermore to this, the specific function formula [word = "CE"] [word = ","] [word = "TS"] [word = ","] [word = "specific TS"] was used and the frequency and percentage of each strategy are shown in Fig. 15 and by bar graph in Fig. 16.

CEs mainly include unique Chinese historical culture, poetic references, religious terminology or references to Chinese operas (dramas), or art. Translation of these terms should prioritise principles of correctness, completion, clarity, acceptability and readability (Wang 2017). The analyses show that to achieve these principles, translators of CEs adopted four main strategies and thereby also align with the three dimensions of Eco-translatology (linguistics, communication and culture). As can be seen from the bar chart, Literal Trans (34.1\%) accounts for the largest use. Within the Literal Trans category, there are two types, historical and religious. The possibility of the successful use of Literal Trans is due to the fact that equivalent words and sentences in SL can be found in the TL. For example, '耕读文化' was translated into 'farming-study culture'; “观音' was translated
Fig. 15 Applied translation strategies in CEs

\begin{tabular}{ccc}
\hline Translation strategies & Frequency & Percentage \\
\hline TF Trans & 129 & $29.79 \%$ \\
Free Trans & 84 & $19.40 \%$ \\
Literal Trans & 148 & $34.18 \%$ \\
Addition & 72 & $16.63 \%$ \\
Total number & 433 & $100 \%$ \\
\hline
\end{tabular}


Fig. 16 Percentage of translation strategies in CEs

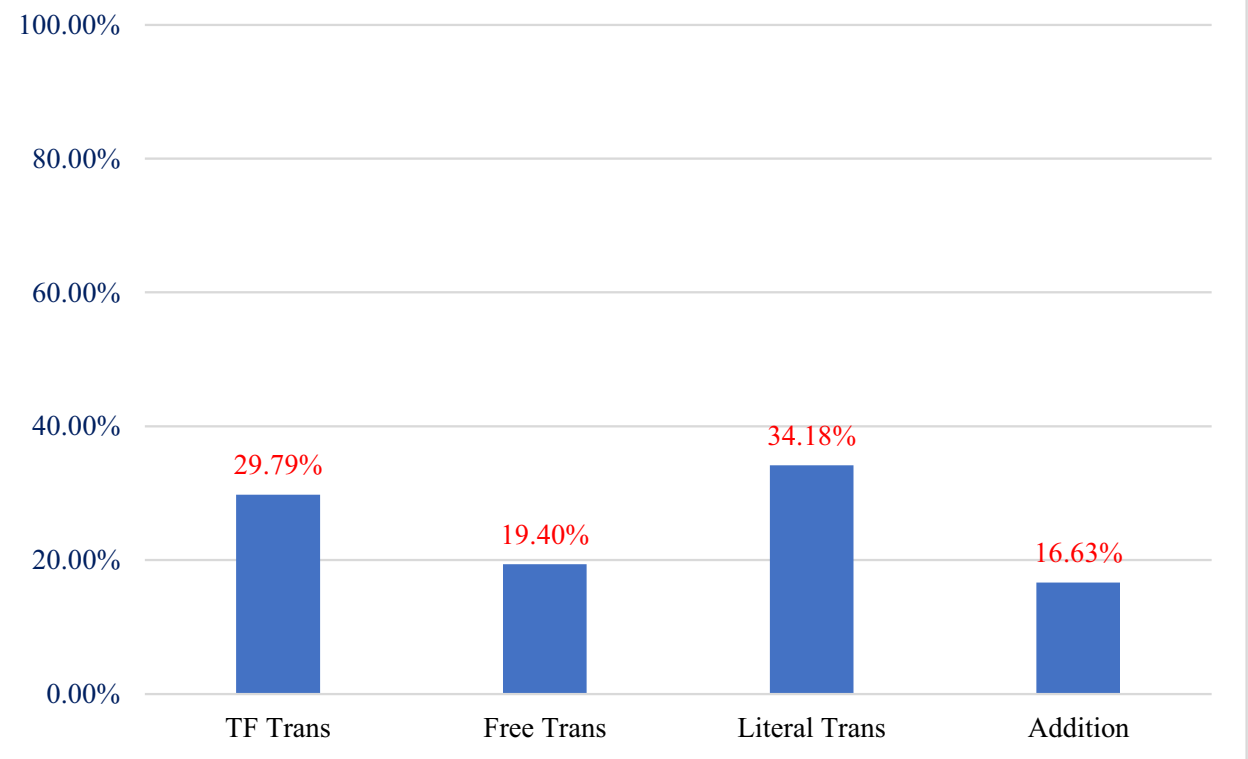

into 'Avalokitesvara', and ‘佛寺' became 'Buddhist temple'. If the semantic and pragmatic values are consistent with the ST, the translator can use the corresponding words in the TL to translate the cultural information in the SL. Thus, transformation of the cultural and communicative dimension of Eco-translatology is fulfilled. Another example, in the analysis of the PGC, is two lines of poetry rendered by Literal Trans. These are the following:

ST 18: < s > 此景南宋已发现, 有诗句云“抱儿爱均于慈 母, 正是说的这处景观。 $</ \mathrm{s}>$

TT 18: <s $>$ A poem of the Southern Song Dynasty likens this scenery to 'Endless love from the mother nursing her baby.' $<\mathrm{CE}$, TS, Literal Trans $></ \mathrm{S}>$

ST 19: $<\mathrm{s}>$ 雁荡山景区素有 “海上名山, 寰中绝胜”之 誉。 $</ \mathrm{s}>$

TT 19: $<\mathrm{s}>$ Yandang Mountain Scenic District is claimed to enjoy 'a famous mountain in the sea, an unsurpassed wonder in the world.' $<\mathrm{CE}$, TS, Literal Trans $></ \mathrm{S}>$

These use literal strategy because the common feature is the non-specific cultural image. The poets have used universal objects in nature to express their thoughts and feelings. This image is intended to evoke the abstract feeling of love. Therefore, when dealing with these universal, culturally neutral images, translators can use literal translation to find equivalent meaning. The line in Text 18 was selected from The Ode to Yandang Mountain in the Song Dynasty which was used to describe the ‘抱儿峰 (Nursed Baby’s Peak)'. Literal Trans was used to praise the transcendence of maternal love. Similarly, the line in Text 19 was used to interpret the Yandang Mountain Scenic District. The translator also used Literal Trans to praise the magnificence of Yandang Mountain Scenic District.
TF Trans (29.79\%) also plays a key role in rendering Chinese CEs. In the PGC, mention of local operas and local cultural heritage was translated by TF Trans. Characteristically here, the former part is a proper Chinese noun, usually a Chinese place name, and the latter part is a common noun. For example, ‘昆曲' was translated into 'Kun Opera'. The former part '昆 (Kun)' represents the abbreviation of the Chinese place name ‘昆山 (Kunshan)' located in Jiangsu Province. The latter part is common noun '曲 (Opera)'. Similarly, '上山面制作技艺' was translated into 'Shangshan Noodle Making Skills'. The former part, a Chinese place name ‘上山 (Shangshan)', is in Zhejiang Province, and the latter part is a common noun phrase '面制作技艺'. Therefore, when translating these CEs, transliteration was used for the former proper nouns and free translation was used for the common nouns.

Free Trans (19.40\%) was employed to translate some historical and poetic terms. Some Chinese CEs may contain rich complex cultural connotations. Simple transliteration, TF Trans or literal translation, cannot nuance the deeper meaning. For example, the Qing Dynasty's official personnel selection system ‘科举考试' was translated into 'imperial examination'. Therefore, the English translation of the Chinese cultural keyword ‘科举考试' should be expressed by free translation. It was a system used to select talents in the dynasties from the Sui Dynasty to 1905 . This includes English cultural background and expression habits. In addition, Free Trans is also used in the PGC to translate Chinese classical poetry with cultural images. In these poems, the poet uses words with strong cultural colour, such as unique Chinese personal names, place names and allusions, to express their thoughts and feelings and create an original poetic concept. Zhou (2009) explains that generally most 
cultural images crystallise the historical and cultural wisdom of each nation, and are closely related to the legends and totems at the birth of each nation. For example,

ST 20: $<\mathrm{s}>$ 愿借灵湫水, 一洗了堂碑。 $</ \mathrm{s}>$

TT 20: $<$ s $>$ I would like to borrow the water from the Spirit Pool to cleanse the Fulfillment Hall Monument once and for all. $</ \mathrm{s}>$

In this line, '了堂碑' is an allusion. The background to this famous poem is that Qin Hui (1090-1155) was an infamous ancient Chinese official who served as governor of Wenzhou in the fifth year (1135) of the Shaoxing administration. He travelled to Guanyin Cave on a trip to the Yandang Mountain where he found the cave similar to the stone chamber which had appeared in his dream. He was so impressed that he not only wrote a poem about it but erected the 'Fulfillment Hall Monument' in the Guanyin Cave to increase his own importance. However, Wang Shipeng (1112-1171), a renowned ancient Chinese official, was indignant at Qin Hui's action, thinking that the 'Fulfillment Hall Monument' had tarnished the famous sacred mountain and its cave. Shipeng in his response poem urged the Elder Hui of the Lingyan Peak to use his authority and eradicate the monument. In the poem, Shipeng expresses his wish for the sacred waters from Dalong Waterfall to cleanse the stains brought by the 'Fulfillment Hall Monument'. By this well-known literary piece (five characters in each line), Wang Shipeng praises the scenery of the Yandang Mountain, criticising Qin Hui's shamelessness and expresses his wish for the restoration of the mountain's dignity.

As the following examples show, addition is sometimes necessary in CE translation to deal with religious, historical and artistic culture in the PGC.

ST 21: $<\mathrm{s}>$ 永嘉出 604名进士, 宋、明代出状元 12 名。 $</ \mathrm{s}>$

TT 21: $<$ s $>$ Yongjia was the birthplace of 604 Jinshi (successful candidates in the highest imperial examination) $<\mathrm{CE}$, TS, Addition $>$ in the nearly 1,000 years from the Tang Dynasty to the Qing Dynasty and 12 Zhuangyuan (No. 1 scholar in imperial examination) $<\mathrm{CE}$, TS, Addition $>$ in the Song and Ming dynasties. $</ s>$
ST 22: $<\mathrm{s}>$ 现存的苍坡村是九世祖李嵩于南宋淳熙 五年 (1178年) 邀请国师李时日按五行风水说, 重建的村 落。</s $>$

TT 22: $<$ s $>$ The existing village was reconstructed in 1178 by Li Shiri, teacher of the Southern Song Dynasty, and $\mathrm{Li}$ Song, ninth ancestor of the Li family, based on feng shui (China's five-element and geomantic theories) $<\mathrm{CE}$, TS, Addition $>.</ \mathrm{s}>$

ST 23: $<s>$ 东、西两池为 “砚池”。 $<\mathrm{s}>$

TT 23: $<\mathrm{s}>$ Two ponds in the eastern and western village are known as Yanchi Pond, which means an ink stone for making ink $<\mathrm{CE}$, TS, Addition $>.</ \mathrm{s}>$

Texts 21 to 23 involve historical, religious and artistic culture respectively that require some kind of addition. In Text 21 , “进士' and '状元' are the grades of imperial examinations in Chinese dynasties. In Text 22, ‘风水' was related to Chinese Taoism. In Text 23, “砚池” was used, a term which relates to a tool for grinding ink for Chinese calligraphy. It is noteworthy that Text 23 has a small difference because TF Trans strategy is combined with addition to translate. Generally, it has become evident that cultural words can have both implicit (hidden) meaning and no equivalent terms in English. Therefore, in such cases, transliteration or TF Trans should be used to retain the original connotation. Besides this, addition can supplement the implied meaning of cultural words, and fill the cultural gap. Before summarising the pattern of strategies for CEs and extending the model and recommendations for translators, this paper will examine mistranslation in the PGC.

Due to differences between Chinese and Western culture, translators inevitably encounter translation problems, which can result in confusion. The function formula [word= "CE"] [word = ","] [word = "TP"] was used to retrieve to find translation problems in the PGC in the CEs category. The total frequency was 63 and analysis of the concordance results showed there were four types of translation problem: ITSN, Mistranslated, UCPREW and NT. After this, the function formula [word = "CE"] [word = ","] [word = "TP"] [word = ","] [word = "specific TP"], was used to count frequency of every specific problem category. The specific
Fig. 17 Translation problems in CEs

\begin{tabular}{ccc}
\hline Translation problems & Frequency & Percentage \\
\hline UCPREW & 15 & $23.81 \%$ \\
Mistranslated & 15 & $23.81 \%$ \\
NT & 9 & $14.28 \%$ \\
ITSN & 24 & $38.10 \%$ \\
Total number & 63 & $100 \%$ \\
\hline
\end{tabular}


statistics resulting are shown in Fig. 17 and by bar chart in Fig. 18.

Translation problems mainly focus on historic, artistic and poetic culture. Historic and artistic cultures were mainly ITSN (38.10\%), UCPREW (23.81\%) and Mistranslated (23.81\%). This contrasts with the translation problems of poetic culture, NT (only 14.28\%). Some examples below are analysed in Fig. 19.

In Text 24, '太学正' and '国子司业' are UCPREW mistranslations. In Chinese history, these two terms were central government positions which were related to educational status titles. The translator used transliteration to translate them which cannot reflect the cultural implications of the SL. According to the above analysis, for this type of term, it is recommended to use addition strategy. Therefore, '太学正' should be translated into 'Taixue zheng (College Supervisor in the Song Dynasty)' and '国 子司业' should be rendered into 'Taizi siye (Vice Director of Education in the Song Dynasty)'. In Text 25 and Text 26, ‘永嘉学派, ‘永嘉四灵' and “瓯窑” are ITSN. The feature of term '永嘉学派' is similar to '耕读文化 (farming-study culture)' which is in the above literal translation examples. Because ‘永嘉学派' is a Chinese school of thought, it was rendered into 'Yongjia School of Thought' via Literal Trans to reflect its meaning. ‘永嘉四灵' should be corrected and translated into 'Four Poets of Yongjia (Zhao Shixiu, Xu Ji, Xu Zhao and Weng Juan)', because the word ‘灵 (líng)' in '永嘉四灵' was used either in their style or in their literary name. In Text 26, there were three translated versions of '瓯窑'. As a School of Chinese Art, it cannot express the implicit meaning to target readers through simple and direct translation. Therefore, it should be translated into 'Ou Porcelain Wares (Chinese Ceramics)'. In Text 27, ‘文房四宝' and ‘安史之乱’ were Mistranslated. ‘文房四宝' are unique calligraphy and painting tools in China. The translator used literal translation to translate which also cannot express the implicit meaning. It should use addition to reveal the implicit meaning. Hence, it should be improved to read 'The Four Treasures of Study (Brush, Inkstick, Paper, and Inkstone)'. The term '安史之 乱' refers to one of the most famous rebellions in Chinese history. It was a political rebellion in the Tang Dynasty which was initiated by An Lushan and Shi Siming for control of the central government. The features of this term are also similar to '耕读文化 (farming-study culture)'. Thus, it should be translated into 'Rebellion of An Lushan and Shi Siming' via Literal Trans. In Text 28, an allusion '天 孙' was omitted and not translated. In Chinese culture, '天 孙' means “织(zhī: wave)女(nü: girl/woman)' which was a legend that should be translated (Free Trans) into 'the Divine Spinning Damsel'. Again, improvement is reached through the principles of Eco-translatology.

In conclusion, when researching the translation strategies in CEs, quantitative and qualitative analysis on the PGC was conducted and various examples have been presented for consideration of the relevant translation strategies. Finally, according to Eco-translatology, mistranslations were analysed and corrected. Hence, accordingly, the four translation strategies (Literal Trans, TF Trans, Free Trans and Addition) are recommended for translating CEs. Fig. 20 summarises and clearly models the successful strategies and their corresponding examples.
Fig. 18 Percentage of translation problems in CEs

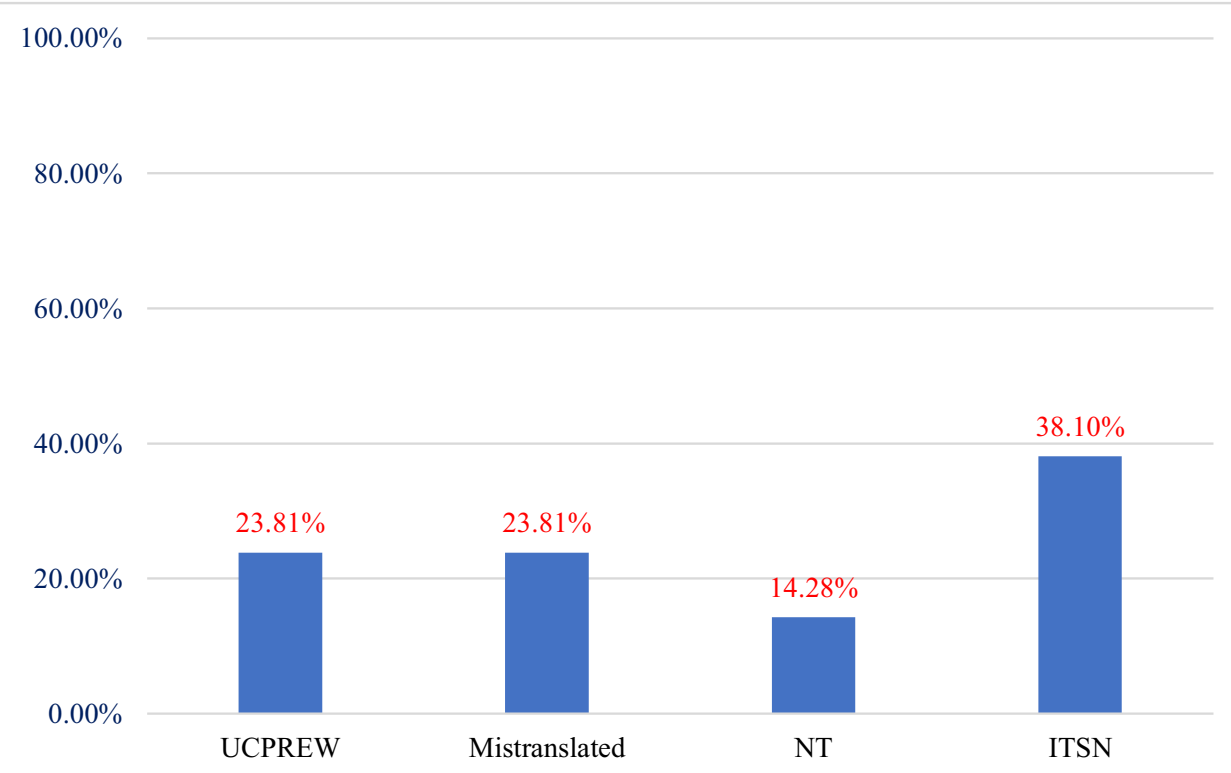


Fig. 19 Typical examples of translation problems in CEs

\begin{tabular}{|c|c|c|c|}
\hline Text & ST & TT & Translation Problems \\
\hline 24 & $\begin{array}{l}<\mathrm{s}>\text { 叶适是一位大教育 } \\
\text { 家, 一生从事教育 } 30 \text { 余 } \\
\text { 年, 曾任太学正和国子 } \\
\text { 司业。</s> }\end{array}$ & $\begin{array}{l}<\mathrm{s}>\text { As a notable educator, Ye Shi took up } \\
\text { education for } 30 \text {-odd years. }</ \mathrm{s}><\mathrm{s}>\mathrm{He} \text { once } \\
\text { served as } \underline{\text { Taixuezheng }<\mathrm{CE} \text {, TP, UPREW }>} \\
\text { and } \underline{\text { Guozisive }}<\mathrm{CE} \text {, TP, UCPREW }>.</ \mathrm{s}>\end{array}$ & UCPREW \\
\hline 25 & $\begin{array}{l}\text { (1) }<\mathrm{s}>\text { 两宋时期, } \\
\text { “永嘉学派”、“永嘉 } \\
\text { 四灵’ 在中国文化史上 } \\
\text { 有着显著的地位。 }</ \mathrm{s}>\end{array}$ & $\begin{array}{l}\text { (1) }<\mathrm{s}>\text { During the North Song Dynasty and } \\
\text { Southern Song Dynasty, 'Yongiia School' } \\
<\mathrm{CE} \text {, TP, ITSN }>\text {, and ' } \underline{\text { Yongjia Four Poets' }} \\
<\mathrm{CE} \text {, TP, ITSN }>\text { had significant status in } \\
\text { Chinese cultural history. }</ \mathrm{s}>\end{array}$ & ITSN \\
\hline & $\begin{array}{l}(2)<\mathrm{s}>\text { “永嘉学派”、和 } \\
\text { “永嘉四灵” 是中国文 } \\
\text { 化史上光辉灿烂的篇 } \\
\text { 章。 }</ \mathrm{s}>\end{array}$ & $\begin{array}{l}(2)<\mathrm{s}>\text { ' } \text { Yongiia School of } \text { Thought' }<\mathrm{CE} \text {, } \\
\text { TP, ITSN }>\text {, and 'Yongiia School of } \\
\text { Poetry' }<\mathrm{CE}, \text { TP, ITSN }>\text { are all brilliant } \\
\text { chapters in the history of Chinese culture. }</ \mathrm{s}>\end{array}$ & \\
\hline 26 & $(1)<s>$ 瓨窑文化 $</ s>$ & (1) $<$ s $>$ Ou Kiln Culture $<$ CE, TP, ITSN $><$ s $>$ & ITSN \\
\hline & $\begin{array}{l}(2)<s>\text { “㼛窑” 是楠溪江 } \\
\text { 流域人民智慧结晶的见 } \\
\text { 证, 也是永嘉历史文化 } \\
\text { 的代表。 }</ s> \\
(3)<s>\text { 北宋瓨窑青釉 }</ s>\end{array}$ & $\begin{array}{l}\text { (2) }<\mathrm{s}>\text { ' } \underline{\text { Ou chinaware' }}<\mathrm{CE}, \mathrm{TP}, \text { ITSN }> \\
\text { represented the great wisdom of people living } \\
\text { on the Nanxijiang River }<\mathrm{GF}, \mathrm{TP}, \\
\text { ITSN }>\text { Basin and signified the } \\
\text { importance. }</ \mathrm{s}> \\
(3)<\mathrm{s}>\text { Cyan glaze chinaware of } \underline{\text { Ouyao }} \\
\underline{\text { Kiln }}<\mathrm{CE} \text {, TP, ITSN }>\text { which was made in } \\
\text { North Song Dynasty }</ \mathrm{s}>\text {. }\end{array}$ & \\
\hline 27 & $\begin{array}{l}<\mathrm{s}>\text { 苍坡古村落至今已有 } \\
840 \text { 年的历史, 平面上略 } \\
\text { 呈方形, 以笔架山为地 } \\
\text { 标, 依 “文房四宝” 布 } \\
\text { 局建设。 }</ \mathrm{s}>\end{array}$ & $\begin{array}{l}<\mathrm{s}>\text { With a history of nearly } 840 \text { years, it is a } \\
\text { square-shaped village constructed through the } \\
\text { layout of the 'scholar's four treasures' }<\mathrm{CE} \text {, } \\
\mathrm{TP} \text {, Mistranslated }>\text { and taking Pen Stand } \\
\text { Mountain }<\mathrm{GF} \text {, TS, Literal Trans }>\text { as its } \\
\text { landmark. }</ \mathrm{s}>\end{array}$ & Mistranslated \\
\hline & $\begin{array}{l}<\mathrm{s}>\text { 隋唐时期, 尤其 “安 } \\
\text { 史之乱” , 进一步促进 } \\
\text { 人们向楠溪江中游一带 } \\
\text { 扩散。 }</ \mathrm{s}>\end{array}$ & $\begin{array}{l}<\mathrm{s}>\text { In Sui and Tang Dynasties, the 'Anshi } \\
\underline{\text { Riot' }}<\mathrm{CE} \text {, TP, Mistranslated }>\text { in particular } \\
\text { further pushed people to migrate to the middle } \\
\text { reaches of the Nanxijiang. }<\mathrm{GF}, \mathrm{TP} \text {, } \\
\text { ITSN }></ \mathrm{s}>\end{array}$ & \\
\hline 28 & $\begin{array}{l}<\mathrm{s}>\text { 龙湫飞泉酒绝顶, 万 } \\
\text { 丝下浣天孙机。</s> }\end{array}$ & $\begin{array}{l}<\mathrm{s}>\text { The flying spring from the Dalong } \\
\text { splashes from a pinnacle. Ten thousand silk- } \\
\text { like water columns rush down to wash a loom. } \\
<\mathrm{CE}, \mathrm{TP} \text {, Mistranslated }>.</ \mathrm{s}>\end{array}$ & NT \\
\hline
\end{tabular}


Fig. 20 Taxonomy of translation strategies in CEs

\begin{tabular}{|c|c|}
\hline Translation strategies & Categories in CEs \\
\hline Literal Trans & $\begin{array}{l}\text { (1) Translating CEs which can be found with words of cultural } \\
\text { equivalence in English or fixed collocations in English which were } \\
\text { accepted by target readers, such as '耕读文化 (farming-study } \\
\text { culture)' and '安史之乱 (Rebellion of An Lushan and Shi } \\
\text { Siming)' . } \\
\text { (2) Translating poems with non-cultural image, such as Texts } 19 \text { and } \\
\text { 20. }\end{array}$ \\
\hline TF Trans & $\begin{array}{l}\text { Translating CEs which consisted of two parts: the former part is } \\
\text { proper noun, and the latter part is common noun. The former part } \\
\text { used transliteration and the latter part used free translation, such } \\
\text { as '昆曲 (Kun Opera)' }\end{array}$ \\
\hline Free Trans & $\begin{array}{l}\text { (1) Translating highly concentrated Chinese CEs which contain rich } \\
\text { cultural connotations. Other strategies cannot reveal the connotation } \\
\text { in the CEs, such as '科举制 (imperial examination)' }\end{array}$ \\
\hline & $\begin{array}{l}\text { (2) Translating poems with cultural images which include strong } \\
\text { cultural colours including allusions and personal names, such as '了 } \\
\text { 堂碑 (the Fulfillment Hall Monument)' and '天孙 (The Divine } \\
\text { Spinning Damsel)'. }\end{array}$ \\
\hline Addition & $\begin{array}{l}\text { Translating CEs which have two features: implicit meaning and no } \\
\text { words of cultural equivalence in English. }\end{array}$ \\
\hline
\end{tabular}

\section{Conclusion}

This paper has argued that more effective translation strategies are urgently required in the field of geotourism and can be employed using this type of research which employs corpus methodology and Eco-translatology theory. All the data were analysed quantitatively and qualitatively to develop effective strategies for translation according to their geotourism category. Finally, these effective strategies in GF, GP and CE were summarised to form a taxonomy of geotourism translation from Chinese to English based on Hu's Eco-translatology. The taxonomy will contribute to Eco-translatology-based translation strategy and to the standardisation of geotourism translation (GF, GP and CE). Meanwhile, this new theoretical guidance will provide a reference for translators engaged in geotourism translation in the future. It is hoped the creation of an inaugural taxonomy of geotourism translation strategies, based on Hu's Eco-translatology, will lift the professionalism of geotourism translation from Chinese to English. To summarise the structure of the taxonomy, at GF level, literal translation, transliteration and free translation, addition, official UNESCO names, foreignisation and shift translation were used (foreignisation and shift as minor translation strategies were employed as well in certain situations). At GP level, DS Trans, Literal Trans, Shift and division were employed. At CE level, Literal Trans, TF Trans and addition were adopted. The structure of the taxonomy clearly emerged through the analyses carried out on the PGC.

The implications of the findings of this research provide, above all, a professional approach to geotourism (a system for future geotourism standards of excellence) that will fulfil the balance of data and engagement that this genre demands. Also, there are insights for the broad field of translation (a systematic method of approaching translation through corpus and Eco-translatology), as well as potential material at various levels of translation education (provision of a rich bank of educational resources). It is also intended that this research provides criteria to inform standardisation of geotourism translation choices. The corpus itself (PGC) provides a reference tool for future geotourism and geopark translators. Meanwhile, more broadly, it is hoped the 
innovative nature of this research will germinate interest and development in future geotourism translation. Moreover, in education, by providing authentic environment data, lecturers can demonstrate more effective translation strategies to teach techniques for translation, quality standards and consequent respect for geotourism translation into English.

The context of geotourism's recent development means the data is selected in a specific area and time which means in terms of strictly random selection, the data choice is narrow. The researchers attempted to compensate somewhat for this by selecting renowned, well-established geoparks, a range of features and quantitatively representative examples across Chinese geoparks and geoheritage. Based on these research limits, the PGC may not be as large as some may have desired or expected. This size limitation may lead to some errors of assumption in the analysis of patterns, or a lack of representativeness of the breadth of translation challenges. Therefore, it is possible that the proposed new translation theory needs further refinement. In response to the above limitations, further improvements could be made to meet technical and cultural challenges of translating from Chinese into English.

\section{Appendix}

Table 13 Comprehensive list of linguistic terms

\begin{tabular}{|c|c|c|}
\hline NO & Linguistic terminology & Comments \\
\hline 1 & Addition & $\begin{array}{l}\text { Adding some words or a clause in translation to fully explain the information of implicit or cultural meaning } \\
\text { of source text to the target readers }\end{array}$ \\
\hline 2 & Annotation (Tagging) & $\begin{array}{l}\text { For control in research, special symbols are used to annotate the translation strategies. They are used to facili- } \\
\text { tate retrieval in the corpus. (Thus a corpus can easily be used to carry extra linguistic information.) }\end{array}$ \\
\hline 3 & Cultural equivalence & The same value in cultural terms but in words directly meaningful to the target history and social system \\
\hline 4 & Corpus linguistics & $\begin{array}{l}\text { A type of research that studies language using repetitions of a category, word or part of speech. It mainly } \\
\text { studies machine-readable natural language texts and is particularly suitable for quantitative language analy- } \\
\text { sis, lexicography and machine translation }\end{array}$ \\
\hline 5 & Division & $\begin{array}{l}\text { Translation strategy which divides the long sentence into several small parts, which share a connected mean- } \\
\text { ing }\end{array}$ \\
\hline 6 & Division and Shift & A compound translation strategy combining two strategies, namely division and shift, NO. 5 and 14 \\
\hline 7 & Foreignisation & $\begin{array}{l}\text { Translation strategy where the target text is prioritised to align to the reader's own native language so synthe- } \\
\text { sis takes place to deliver the closest approximation which could be phonetic or by other means }\end{array}$ \\
\hline 8 & Free translation & Translation strategy focused on the content of the original without retaining the form of the source text \\
\hline 9 & Literal translation & $\begin{array}{l}\text { Translation strategy rendering the text word-by-word while maintaining the form and content of the source } \\
\text { text }\end{array}$ \\
\hline 10 & Manually aligned & $\begin{array}{l}\text { A research technique where the machine is not programmed to perfectly align the source text and the target } \\
\text { text correspondingly in every case. This means some adjustment by hand is required to tidy up the cor- } \\
\text { responding order }\end{array}$ \\
\hline 11 & Official name used by UNESCO & Some official names or terms were already available in official use such as UNESCO \\
\hline 12 & Parallel geotourism corpus & $\begin{array}{l}\text { Data is arranged in its typical repetitive categories but also has a one to one correspondence between English } \\
\text { and Chinese geotourism text }\end{array}$ \\
\hline 13 & Semantic equivalence & Terms of languages are equal in meaning but not necessarily the same forms of grammar \\
\hline 14 & Shift & $\begin{array}{l}\text { Translation strategy using change of word/s, sentence structure or voice of the source text in order to fit the } \\
\text { target language }\end{array}$ \\
\hline 15 & Style equivalence & $\begin{array}{l}\text { Translation strategy where the appropriate level of language such complex and simple vocabulary/sentences, } \\
\text { as well as formal and informal approach, is used }\end{array}$ \\
\hline 16 & Translation theory & $\begin{array}{l}\text { This theory is built on recognition of the sound basis for understanding how a language functions, and } \\
\text { acknowledgements that various languages have different formats. It directs translators to preserve meaning } \\
\text { by using the most appropriate forms for the language }\end{array}$ \\
\hline 17 & Translation strategy & A method of translating a linguistic unit from one language to another \\
\hline 18 & Transliteration & $\begin{array}{l}\text { A special translation method where symbols in one language system are transferred to express the letter sym- } \\
\text { bols in another language system. For instance, '浙江' in Chinese is translated into 'Zhejiang' in English }\end{array}$ \\
\hline 19 & Transliteration and free translation & $\begin{array}{l}\text { Sometimes, these two strategies NO. } 8 \text { and } 18 \text { are combined during translation process because they are both } \\
\text { necessary for an effective result }\end{array}$ \\
\hline
\end{tabular}


Acknowledgements Many thanks for parallel geotourism data (Chinese and English) provided by GSA and Dr Young Ng. Furthermore, Dr Young Ng also offered some initial background assistance from his extensive geotourism knowledge and experience. I also wish to express my gratitude to the two anonymous reviewers for their detailed, constructive and helpful comments on an earlier draft of the manuscript, which helped focus and structure the present article, while also suggesting direction for future research.

Author Contribution Qiang (Jason) Li, as the corresponding author and Author 1, shaped the PGC by using the Sketch Engine including manually aligning the corpus, and tagging translation strategies in the corpus. Jason also wrote the paper. As an expert, Dr Young Ng, substantially contributed to the original corpus data. He also provided background knowledge and helpful suggestions about geotourism to Jason and Ruixue (Rachel) Wu through Zoom meetings. Rachel offered technical supervision to Jason in tagging the corpus, and gave advice through Zoom meetings about the structure and revision of this paper. Before submitting this paper, Young carefully read it and offered many insightful comments. Jason then revised it again, considering comments from two reviewers.

\section{Declarations}

Conflict of Interest The authors declare no competing interests.

Open Access This article is licensed under a Creative Commons Attribution 4.0 International License, which permits use, sharing, adaptation, distribution and reproduction in any medium or format, as long as you give appropriate credit to the original author(s) and the source, provide a link to the Creative Commons licence, and indicate if changes were made. The images or other third party material in this article are included in the article's Creative Commons licence, unless indicated otherwise in a credit line to the material. If material is not included in the article's Creative Commons licence and your intended use is not permitted by statutory regulation or exceeds the permitted use, you will need to obtain permission directly from the copyright holder. To view a copy of this licence, visit http://creativecommons.org/licenses/by/4.0/.

\section{References}

Arifin Z (2019) Translation strategies of culture-specific terms in the tourism text Â€CEwisata Kuliner Di Kota Batikâ€. ADJES (Ahmad Dahlan Journal of English Studies), 6(1): 37-44. https:// doi.org/10.26555/adjes.v6i1.8676

Dowling RK, Newsome D (2006) Geotourism issues and challenges. In: Dowling RK, Newsome D (eds) Geotourism. Burlington, Oxford, pp 242-254

Dowling RK (2013) Global geotourism - an emerging form of sustainable tourism. Czech Journal of Tourism 2(2):59-79. https:// doi.org/10.2478/cjot-2013-0004

GSA website (2015) Retrieved May 9, 2015, from https://www.gsa.org. $\mathrm{au} /$ Public/Geotourism/Public/Geotourism/Geotourism\%20and\% 20Geotrails.aspx hkey=754eb036-9266-452e-95b8-e135a1db04 d1

Gordon JE (2018) Geoheritage, geotourism and the cultural landscape: Enhancing the visitor experience and promoting geoconservation. Geosciences (switzerland) 8(4):1-24. https://doi.org/10.3390/ geosciences 8040136

Han C, Wang K (2014) Subtitling swearwords in reality TV series from English into Chinese: a corpus-based study of the family. The
International Journal of Translation and Interpreting Research, 6(2): 1-17. https://doi.org/10.12807/ti.106202.2014.a.01

Hose TA (1996) Geotourism, or can tourists become casual rock hounds? In: Bennett MR (ed) Geology on your Doorstep. The Geological Society: London, UK, pp 207-228.

Hu GS (2001) A preliminary study: an approach to translation as adaptation and selection [Conference Presentation]. Translation in the New Millennium: Inter-Continental Perspectives on Translation, Hong Kong (SAR), China.

Hu GS (2003) Translation as adaptation and selection, Perspectives: Studies in Translatology, 11(4): 283-291. https://doi.org/10.1080/ 0907676X.2003.9961481

Jakobson R (1959) On linguistics aspects of translation. In: Fang A et al (ed) On Translation. Mass: Harvard University Press: Cambridge, pp 232-239.

Joyce EB (2006) Geomorphological sites and the new geotourism in Australia. Geological Society of Australia, Melbourne. Retrieved from http://web.earthsci.unimelb.edu.au/Joyce/heritage/geoto urismReviewebj.htm

Li SH (2019) A corpus-based multimodal approach to the translation of restaurant menus. Perspectives: Studies in Translation Theory and Practice, 27(1): 1-19. https://doi.org/10.1080/0907676X. 2018.1483408

National Geographic (2005) Geotourism Chater https://www.natio nalgeographic.com/maps/topic/geotourism

Newmark P (1988) A Text Book of Translation. Prentice Hall, Hemel Hempstead

Ng Y (2017) Chinese geotourism and geoparks: selected cases: a review of geopark development in China with a particular focus on three UNESCO Global Geoparks. Travel. https://www.slide share.net/leisuresolutions/chinese-geotourism-and-geoparks-selec ted-cases-dr-young-ng. Accessed 30 November 2017

Rezaei M, Kuhi D (2014) Strategies employed in translation of tourist guidebooks culture-specific items from Persian into English. Theory and Practice in Language Studies 4(4):750-757. https:// doi.org/10.4304/tpls.4.4.750-757

Rabassa G (1989) No two snowflakes are alike: translation as metaphor. The University of Chicago Press, Chicago

Sketch Engine (2003) https://www.sketchengine.eu/

Tmxmall (2014) https://www.tmxmall.com/

UNESCO (1999) UNESCO Geoparks Programme - a new initiative to promote a global network of geoparks safeguarding and developing selected areas having significant geological features: Document $156 \mathrm{EX} / 11$ Rev., Executive Board, $156^{\text {th }}$ session, UNESCO, Paris, 4 p. https://www.geopark.gov.hk/en_s3fg.htm

UNESCO (2021a) https://en.unesco.org/

UNESCO (2021b) http://www.unesco.org/new/en/natural-sciences/ environment/earth-sciences/unesco-global-geoparks/list-of-unesco-global-geoparks/china/danxiashan/

UNESCO (2021c) http://www.unesco.org/new/en/natural-sciences/ environment/earth-sciences/unesco-global-geoparks/list-of-unesco-global-geoparks/china/mount-kunlun/

Wang CY (2017) Study on translating cultural-specific elements in Chinese tourism texts. Advanced in Social Science, Education and Humanities Research. 144: 240-244. Retrieved from file:/// Users/liqiang/Downloads/25881298.pdf

Xiao R, McEnery T, Qian YF (2006) Passive constructions in English and Chinese. Languages in Contrast 6(1):109-149. https://doi. org/10.1075/lic.6.1.05xia

Zhou XJ (2009) Fusion of horizon in cultural image transmission of classical Chinese poetry. Journal of Shenyang Jianzhu University (Social Science). 11(4): 505-508. Retrieved from https://www. ixueshu.com/document/f4413e640aa446b97413e9b008fa1e99318 947a18e7f9386.html 